\title{
LAWYERS AND INFORMAL JUSTICE: THE CASE OF A PUBLIC HOUSING EVICTION BOARD
}

\author{
RICHARD LEMPERT* \\ AND KaRl Monsma $\dagger$
}

\section{INTRODUCTION}

When lawyers think of civil procedure they almost invariably think of the rules of civil procedure and the formality they entail. A course in civil procedure focusing almost exclusively on the Federal Rules of Civil Procedure is in most law schools part of the traditional first-year curriculum. Indeed some would argue that it is at the core of that curriculum, for more than any other first-year course it takes students away from familiar moral anchors and instructs them in a set of distinctively legal practices and values. The ability to manipulate the legal system's rules of procedure is the most general skill in which nascent lawyers are instructed. ${ }^{1}$

But formal rules of civil procedure do not delimit the bounds of civil actions. Many contested civil actions are heard by tribunals or decisionmakers that ignore many if not all of the lawyer's rules of civil procedure as well as associated rules like rules of evidence. These tribunals typically hear the lowstakes disputes that individuals have with each other or with businesses, such as disputes brought to small claims courts, or the disputes that individuals

Copyright (c) 1988 by $L_{a}$ w and Contemporary Problems. Permission to reprint must be pre-cleared with first author.

* Professor of Law \& Sociology. Universicy of Michigan.

+ Center for Research on Social Organization. University of Michigan.

Work on this paper was supported by grant \#SES-8617981 from the law and Social Science Program of the National Science Foundation and by the Cook Funds of the University of Michigan Law School. The cooperation of the Hawaii Housing Authority was essential to this rescarch. We would like to thank the many people associated with the Authority who facilitated this investigation and Professor Paul D. Carrington of Duke Iaw School, who galvanized us to write this article and read and commented on an earlier version. We also thank Gail Ristow for work she did typing this manuscript and for not making us feel guily about the many times we asked her to retype portions of it and the tight deadlines we imposed. All findings and opinions expressed in this paper are the authors' and should not be attributed to the National Science Foundation, the University of Michigan, or the Hawaii Housing Authority.

1. Substantive legal knowledge is essential, but substantive courses deal with particular problems, and lawyers who do not practice in an area are not expected to know much about it even if they took a relevant course in law school. Other lawer skills like negotiation or drafting do cut across areas of practice, but they are thought to be inborn in the lawyer or not distinctively legal. Until recenty courses designed to hone such skills were seldom taught in the nation's law schools, and cven now they tend to be taught in small doses in connection with substantive courses or as limited enrollment electives. 
have with the government over their eligibility for various entitlements or their liability to particular penalties. The latter may involve stakes that are quite high for the individual involved, although perhaps petty from the point of view of the government. ${ }^{2}$

Social scientists often call the procedures in such tribunals "informal" and speak of their decisions as "informal justice," meaning by informal a tendency to follow lay rather than professional-legal modes of introducing and arguing about evidence. Although the point has been cogently-many would say persuasively-disputed, ${ }^{3}$ such informality is commonly thought to be not only a strength of, but also a reason for creating, tribunals that are not bound by the usual rules of legal procedure. One of the purported virtues of informal tribunals is that they are thought to allow litigants who cannot afford, or would be unwise to invest in, legal counsel ${ }^{+}$to comprehend what is occurring, and to present meaningful arguments to the decisionmaker.5

Whether this rationale withstands scrutiny is a matter that need not concern us. The important point is that the informality of informal tribunals is usually an all but inescapable consequence of their design and jurisdiction. Design features that promote informality include staffing by non-lawyer judges, rules that prevent or inhibit the use of attorneys, and procedures that promote conversational modes of presenting and discussing information while limiting or precluding the resort to specifically legal conceptions of what is proper. A tribunal's jurisdiction promotes informality when the matters it encompasses make it likely that litigants will proceed without lawyers or, if represented, proceed in a non-legalistic way.

Even when tribunals are designed to be informal, the absence of lawyers is often not a design feature but a consequence of the tribunal's jurisdiction. In such tribunals, lawyers are permitted-indeed litigants may have a right to proceed through counsel-but lawyers seldom appear either because the litigants see no need for attorneys or because, even if they see a need, they

2. These ypes of disputes do not exhaust the list of civil actions that proceed even in theory with little attention to formal rules of procedure. For example, disputes between regulated industries and the government may be heard initially in informal settings, and civil action substitutes like arbitration and mediation may similarly dispense with the formal rules of court procecdings.

3. Sec the essays collecied in I R. Abel. The Politics of Informal Justice (1982). Sep also 2 R. ABel. The Poitics of Informal Justicf. (1982) (examining informal justice practices and structures from a comparative perspective).

4. Note that there is a social decision here. There is nothing natural about people lacking counsel when they cannot afford it or when the cost would be greater than the amount at stake. Socicty could. as it does for many misdemeanors, subsidize counsel for everyone facing informal hearings. Such a decision might soon transform the informal character of such tribunals while at the same time making informality less necessary. For a discussion of how such a transformation occurred in the workers compensation context. where large stakes relative to lawver cost drove the tansformation, see generally P. Nonet, Administrative Justick: Adocacy and Change in a (G) GRNMENT AGHCY (1969).

5. Conley and O'Barr point out that in the case of the small claims courts they studied, the latter may be an illusion. The failure of litigants to tell stories that touch the requisite legal bases mav cost litigants verdicts even though the litigants feel that they have said evervthing thev wish to say and that the decisionmaker has attended to them. O'Barr \& Conley. Litigrant Satisfaction liersus legeral Adequary in Simall Claims Comm . Aamatizes, 19 L Aw \& Soc'Y Rro. 661, 684-90 (1985). 
cannot acquire attorneys. In these circumstances those lawyers who on occasion happen to represent litigants will find a tribunal that has been shaped without regard for their interests or usual modes of proceeding. The procedures they confront may seem not only unfamiliar but also inappropriate for adjudication. If lay judges preside, lawyers may find that they have to put their arguments in "client vernacular," although they are accustomed to putting clients' stories into legal language. Moreover, because legal representation in such tribunals is rare, many lawyers who do appear will be either infrequent or one-time participants and so will lack the knowledge and other advantages that accrue to repeat players."

Yet even while retaining its informality, a tribunal may be affected by the sporadic appearances of attorneys. It will, for example, want to be certain that it touches any legal bases that apply in the situations it adjudicates, for the occasional appearance of lawyers will make threats of appeal to formal courts on questions of law credible. ${ }^{7}$ Moreover, informal tribunals are not without rules or procedure. ${ }^{\triangle}$ Even the occasional presence of lawyers may lead an informal tribunal to restructure its proceedings, perhaps bringing them more in line with lawyer expectations.

\section{II}

\section{A Public Housing Eviction Board}

We propose to study how lawyers function before informal tribunals by looking at the performance of lawyers before a public housing eviction board. The board has processed all eviction actions brought by the Hawaii Housing Authority ("the Authority") on the island of Oahu since December 1957. We shall, however, look only at the twenty-year period from 1966 through 1985. "

Throughout its history the board has had the power of an ordinary court in deciding whether to evict tenants ${ }^{10}$ and in issuing writs of possession enforceable by the sheriff." However, the procedural rules of ordinary courts do not apply. Although tenants are given notice of the charges, neither side engages in formal discovery; rules of evidence do not structure hearings; testimony is ordinarily delivered in narrative rather than question-and-answer

6. Galanter, II/y the "Ilates" Come Out Ahead: Sperulations on the Limits of Legal Change. 9 Law \& Soc'y REv. 95, 114-19 (1974).

7. The relationship of informal courts to formal courts varies by the type of tribunal and by the problems with which it deals. In some instances informality, which may extend to the denial of certain basic rights such as the right to counsel, is justified because the parties must consent to the tribunal's jurisdiction and/or a party dissatisfied with the tribunal's decision has a right to a de novo trial in a more formal court. In other instances review by more formal courts may be limited to questions of law including. perhaps, the issue of whether the factual findings of the informal tribunal were supported by substantial evidence.

8. See Lempert, The Dynamics of Informal Procedure: The Case of a Public Housing Eziclion Board. LAw \& Soc'Y REviEw (forthcoming 1989) [hercinafter Dymamies].

9. Our current data set only covers this period. At one lime, however, the first author cxamined data from 1957 through June 1969 . During the period from 1957 to 1966 lawyers were almost never present.

10. Haw. Rer. STar. $\$ 360-5(1980)$ as amended.

II. It. 
fashion; and board members feel free to question and on occasion even lecture tenants and other witnesses. Indeed, when in 1980 the Authority sought to regularize the status of the board by adopting formal administrative rules governing the board's powers and proceedings, one of the rules it enacted provided: "Hearings shall be conducted in an informal manner unless otherwise required by law." 12

Appeal from the board's decision is to the Commissioners of the Authority and beyond them to the Circuit Court for the First Circuit of Hawaii. Until 1980 the Commissioners heard appeals de novo and for some time after that they would hold hearings to determine if "new facts and evidence" sufficient to trigger an appeal were present. ${ }^{13}$ In 1984 the task of determining whether an appeal met the new facts and evidence standard was delegated to the Executive Director, and since then appellate hearings have been pro forma ratifications of stipulated agreements that the tenant has made with the executive staff. ${ }^{14}$

Tenants may be represented by lawyers at or before the hearing, after the hearing but before an appeal has been filed, after filing for an appeal, or after the appeal. Lawyers may represent tenants at only one stage or at various stages, beginning, for example, before the hearing and ending after an appeal.

The Authority's eviction board (now called the "hearing board") is composed entirely of non-lawyers. From 1966 through 1969 the board consisted of five citizen volunteers. In 1970 two tenants were added to the board, and in October 1979 a second seven-member panel was added so that cases could be heard every week rather than every other week without unduly burdening the board members. During the late 1960's and throughout most of the 1970's a large proportion of the non-tenant members of the board were people whose professional or other volunteer activities were characterized by a special concern for the poor. In the late 1970's, however, the Authority began to look for people with business backgrounds when vacancies arose..$^{5}$ Today, more board members spend their working lives in real estate sales and management than in any other profession.

The board's docket is dominated by cases involving non-payment of rent; over the years non-payment has been the only charge in about three-quarters

12. Haw. ADM. Rules, ch. 501, \$ 17-501-12(c) (effective Jan. 1, 1981).

13. An Amendment to Article 360 in 1980 provided that an appeal to the Commissioners was available only when the tenant could offer new facts and evidence that were not, and could not have been, presented at the hearing. HAw. REv. STAT. $\$ 360-7(c)$ (1980) as amended.

14. The usual new fact or evidence is that a tenant evicted for non-pavment of rent has, since the hearing, paid everything that was owing at the hearing and has paid all rent that has become due between the hearing and the appeal. In these circumstances the Authority enters into a stipulated agreement whereby the tenant waives all rights to hearings or appeals should she violate any lease provision within the next year, and the Authority agrees to withold service of the eviction order that the board has issued and to cancel it if the tenant complies fully with her lease obligations over the succecding 12 months.

15. When the second panel was created in 1979, the original board was split in two, creating seven vacancies, two of which were filled by tenants. 

hearing transcripts which were read. Finally, Authority documents relating to the eviction process and the docket records of most cases involving lawyers were perused for information that could not be captured by simple coding.

\section{IV \\ QUESTIONS OF INTEREST}

This article focuses on lawyers ${ }^{17}$ who represented or otherwise acted on behalf of tenants. Although the Authority has had a lawyer as its "hearing officer" (prosecutor) since 1982, he or she ordinarily proceeds informally, if we may judge by what the first author observed in 1987; and it appears that the fact that the hearing officer is a lawyer rather than a lay specialist has few implications for board action. ${ }^{18}$

Tenants' attorneys represented their clients in different ways. These different styles of representation and their consequences are a central focus of this article. They are interesting not only for what they reveal about how lawyers serve clients in informal tribunals, but also for what they reveal about the different ways in which lawyers can react when confronted with institutions of informal justice. ${ }^{19}$ This article examines both the portrait that quantitative data paint about lawyer involvement in the eviction process and the more textured picture of lawyers' reactions to the eviction process that interviews, transcripts, and Authority records allow us to draw.

We are aware of no other work that focuses on lawyers and informal justice and seeks to trace the style and consequences of legal representation before informal tribunals. ${ }^{20}$ However, we expect that the characteristics and

17. Ordinarily where we use the word "lawyer" or "attorney," we mean to include legal aid paralegals as well. Where we mean to distinguish legal aid lawyers from paralegals we will use the term "supervising attorney," or the context will make this clear.

18. The fact that the hearing officer works full time managing evictions appcars very important, however. See Dynamics, supra note 8 . When a non-lawver fulfilled this role, except for factors idiosvncratic to him as a person, he did not act very differently from the two lawyers who succeeded him. The two lawyers seem as different from each other as they do from their non-lawyer predecessor. Moreover, the pattern of board decisions under the first lawyer is more like the pattern under her non-lawyer predecessor than it is like the pattern that her lawyer successor established.

19. One may also find these styles of lawyering in formal courts, although the mix of styles and the stage of the proceedings at which they are used may differ. We simply do not address the issue of how lawvers perform in formal tribunals.

20. There are some studies that look at styles of representation in the juvenile court after it was supposedly formalized following $I n$ re Gault, 387 U.S. 1 (1967). For example, Professors Stapleton and Teitlebaum examined the performance of specially trained "project" lawyers in two juvenile courts. They found that the clients of the project lawyers did better than unrepresented clients or the clients of non-project lawvers in the court in which the project lawyers took a more legalistic/adversarial approach to representation but not in the court where they lailed to do this. However, it is not clear that the lawyers in the latter court would have done better by being more legalistic/adversarial since their stance was shaped by the conditions in the court before which they appeared. See W. Srapleton \& L. Teiti.ebaum, In Defanse of Youth (1972).

Other studies, most of which were conducted in the United Kingdom. examine the consequences of legal representation before informal tribunals but do not tie consequences to style. The most claborate of these, which we received after this manuscript was in press, is H. Genn \& Y. GenN, THE fafectiveness of Rripfisentation at Tribunals (1989). The Genns examine four tribunals-Social Security Appeal Tribunals, Immigration Adjudicators. Industrial Tribunals, and Mental Health 
implications of legal representation reflect substantial interaction between the type of informal forum, the issues the tribunal must resolve, the client population, caseloads, the factors that link attorneys to clients, and the opportunity to force formal court hearings. Thus, we do not claim to be able to derive a general theory of lawyers and informal justice from our study of the Authority's eviction board. We do think, however, that we shall learn something more about lawyering, about the representation of impoverished clients, and about informal justice from observing lawyers in one setting where they are adrift without their usual procedural anchors. If others are stimulated to do similar work in different settings, a more general theory may emerge.

\section{V \\ LAWYERS AT HEARINGS}

Lawyers were almost never involved in eviction hearings in the 1960's. The reasons were simple. Few tenants could afford lawyers and most did not need lawyers to succeed before the eviction board. Non-payment of rent has always been the most common reason why tenants face the board, accounting over the years for about three-fourths'1 of the board's docket. In only eight of the 160 non-payment-only cases brought between June 1960 and June 1969 was the tenant evicted at the first board hearing. The other tenants either had their cases dismissed or, in the overwhelming majority of cases, were granted conditional deferments."2 When other Authority rules had been violated, such as rules regarding pets, parking, guests, violent behavior, and income reporting, tenants during this period did not fare as well as when nonpayment alone was charged, but even in these cases tenants won a dismissal or a conditional deferment more than half of the time. ${ }^{23}$

The reasons tenants did so well before the board during a period when lawyers were almost never seen is not a central concern of this article. It is sufficient to say that the reasons had to do with the composition of the board, the precedents that the board had developed, and the stance that the Authority's central office staff took toward the board and its cases. ${ }^{24}$ These factors all changed over time as did the presence of attorneys. We are concerned here with that presence-with its magnitude, with its manifestations, and, ultimately, with its consequences for the eviction process.

Review tribunals-and conclude that in cach of them individual parties are aided by representation, although in some lay representation seems as effective as legal representation.

21. Of the 1261 cases subpocnacd between 1966 and 1985 for which we know the cause of action, about $74 \%$ involve only the charge of non-payment of rent while an additional $6 \%$ involve a charge of non-payment along with one or more other charges. In the data we present, the latter cases will be coded in the category of the other charge, for if non-payment alone were sufficient to guarantee an eviction, the Authority would not need to go to the greater trouble of proving some other charge.

22. See R. I empert, Fvictions From Public Housing: A Sociological Inquiry (unpublished Ph.D. dissertation. Univ, of Mich. 1972).

23. $\quad$ ld.

24. Sep generally Dymamirs. supro note 8. 


\section{VI \\ The Magnitude of Lawyer Involvement}

The story of lawyer involvement in the eviction process is in large measure the story of legal aid's willingness to represent tenants, for about 80 percent of those tenants who have had legal representation have been represented by either a legal aid attorney or paralegal. For this reason both the amount and quality of tenant representation over the years has in large measure reflected the policies and priorities of the Legal Aid Society of Honolulu ("LASH").

Table 1 reports, for six time periods, the proportion of docketed cases in which lawyers were involved in some way. The periods in Table 1 are defined substantively. ${ }^{25}$ During the first period the operation and decisions of the board were much like they were before LASH arrived in Hawaii as part of the Johnson Administration's War on Poverty. The second period, 1975-77, was a period when LASH brought several class actions on behalf of Authority tenants and for a time brought the eviction process to a halt. The third period was a bridge period as the Authority, which had undergone sweeping administrative changes, sought to deal with the backlog of cases that were a legacy of the earlier litigation and pondered ways to make its eviction process more rational and efficient.

The last three periods are labeled with letters that represent the Authority's hearing officers. $A$ was the first person the Authority hired with full-time responsibility for managing the eviction process and prosecuting cases before the eviction board. $A$ was not a lawyer, but he saw himself as acting like an attorney in negotiating pre-hearing settlements and in prosecuting cases. The period labeled A runs from mid-October 1979 to January 1982. In fact, $A$ arrived before October 1979, but we commence the period at this point because it marks the establishment of a second eviction panel, which resulted in an infusion of new blood on the eviction board and a marked increase in the rate of hearings. ${ }^{26}$ There was, when $A$ took over, a marked increase in the proportion of non-payment tenants evicted, particularly in cases where less than three months' rent was due. 27 Period B begins when $B$ took over the position of hearing officer in mid-January of

25. Cases that had hearings are classified by the date of the first hearing. Cases that did not have hearings are classificd by the date at which the subpoena was issued.

26. The Authority's primary purpose in appointing a second panel was to be able to have a board meeting each week, thus increasing the pace at which eviction actions could be heard and diminishing the delav between the time of the subpoena and the hearing in the case of individual tenants. The Authority used the institution of a second pancl to divide the existing board and appoint additional members, like private real estate managers, who were expected to have a more "business-like" attitude toward evictions. The Authority also gave all board members a training session at which the Authority's rent collection difficulties and its need for board cooperation were stressed.

27. From 1966 through 1977 no non-payment tenant whose rent debt was three months or less was evicted at the first hearing. In $1978-79$ only one of 14 tenants with a rent debt of three months or less was evicted at the first hearing. Under $A, 32$ of the 88 tenants with such debts were evicted at the first hearing. These figures exclude tenants who paid off their entire debt before the hearing. Before I took over, cases where pre-hearing payment occurred were almost invariably cancelled. Sep Dymamios supra note 8 , at lable 4. 
1982. $28 B$ was the first lawyer to serve as hearing officer. She was officially a deputy attorney general and not in the Authority's chain of command, but for all practical purposes she answered to the head of housing with respect to general eviction policies. The same is true of $C$, a deputy attorney general who replaced $B$ in late February 1984. By the time $C$ quit his post in September 1987 the board was far more likely to evict in non-payment cases than it had been under either $A$ or $B .29$

Turning to Table 1 , we see that while defense counsel are not regularly involved in the eviction process, their involvement is by no means rare, as 108 of the 1268 cases for which we have data contain some indication of lawyer (or paralegal) involvement on a tenant's behalf.

TABLE 1

Percentage of Cases With Lawyers by Period*

PERIOD

\begin{tabular}{lccccccc}
\cline { 2 - 7 } $\begin{array}{l}\text { Percentage } \\
\text { of Cases With }\end{array}$ & $1966-74$ & $1975-77$ & $1978-79$ & $\mathrm{~A}$ & $\mathrm{~B}$ & $\mathrm{C}$ & Total \\
Lawyers & $\begin{array}{c}\mathbf{9} .2 \% \\
(18)\end{array}$ & $\mathbf{6 . 4 \%}$ & $\begin{array}{c}4.3 \% \\
(9)\end{array}$ & $\begin{array}{c}10.5 \% \\
(5)\end{array}$ & $\begin{array}{c}8.7 \% \\
(30)\end{array}$ & $\begin{array}{c}8.2 \% \\
(13)\end{array}$ & $\begin{array}{c}8.5 \% \\
(108)\end{array}$ \\
\cline { 2 - 7 } & 195 & 140 & 115 & 315 & 345 & 158 & 1268 \\
$\begin{array}{l}\text { Total Cases } \\
\begin{array}{l}\text { Commenced by } \\
\text { Subpoena }\end{array}\end{array}$ & 195 & & & & & \\
\hline
\end{tabular}

* Number of cases with lawyers in parentheses.

We see that the rate of lawyer involvement averaged more than 8 percent but was markedly lower during the years 1975-79. This decrease is surprising since we know that from 1975 to 1977 the Authority's eviction board was under severe legal attack by LASH attorneys. In fact, the picture is misleading in that, because of the ongoing litigation and its aftermath, only 25 percent of the cases commenced by subpoena in the 1975-77 period had a hearing, which is less than one-third of the percentage of cases going to hearing in the next lowest period.

Table 2 gives the proportion, by period, of hearings in which tenants had attorneys, and Table 3 gives the proportion of tenants evicted at the hearings who had lawyers on appeal.

28. This was some months after t had left the Authority. We count these months in period $A$ in the expectation that the tone $A$ set is likely to have endured until a permanent replacement was in office. We employ a similar convention in coding the interim between $B$ and $C$.

29. This conclusion is based on interviews and observation. Our quantitative data only run through 1985. To this point they show the board under $C$ distinclly more prone to evict than it was in period B whenever amy rent was owing, but more prone to evict than in period A only when more than three months' rent was owing. 
TABLE 2

Percentage of Cases Going to Hearing With Attorneys at or Before Hearing By Period*

\begin{tabular}{lccccccc} 
& \multicolumn{7}{c}{ PERIOD } \\
\cline { 2 - 8 } $\begin{array}{l}\text { Percentage } \\
\text { of Cases With }\end{array}$ & $1966-74$ & $1975-77$ & $1978-79$ & $\mathrm{~A}$ & $\mathrm{~B}$ & $\mathrm{C}$ & Total \\
Attorneys & $\begin{array}{c}7.5 \% \\
(12)\end{array}$ & $\begin{array}{c}8.8 \% \\
(3)\end{array}$ & $\begin{array}{c}1.2 \% \\
(1)\end{array}$ & $\begin{array}{c}6.8 \% \\
(18)\end{array}$ & $\begin{array}{c}3.2 \% \\
(10)\end{array}$ & $\begin{array}{c}4.1 \% \\
(6)\end{array}$ & $\begin{array}{c}5.0 \% \\
(50)\end{array}$ \\
\cline { 2 - 9 } $\begin{array}{l}\text { Total Number } \\
\text { of Cases Going }\end{array}$ & 159 & 34 & 85 & 266 & 315 & 146 & 1005 \\
to Hearing & & & & & & & \\
\hline
\end{tabular}

* Number of cases with attorneys at or before hearing in parentheses.

TABLE 3

Percentage of Appealed Cases With Attorneys Aiding on Appeal By Period*

\begin{tabular}{lccccccc} 
& \multicolumn{7}{c}{ PERIOD } \\
\cline { 2 - 8 } $\begin{array}{l}\text { Percentage } \\
\text { of Cases With } \\
\text { Altorneys }\end{array}$ & $1966-74$ & $1975-77$ & $1978-79$ & $\mathrm{~A}$ & $\mathrm{~B}$ & $\mathrm{C}$ & Total \\
& $\begin{array}{c}38.9 \% \\
(7)\end{array}$ & $\begin{array}{c}50 \% \\
(2)\end{array}$ & $\begin{array}{c}11.8 \% \\
(2)\end{array}$ & $\begin{array}{c}23.2 \% \\
(16)\end{array}$ & $\begin{array}{c}16.7 \% \\
(15)\end{array}$ & $\begin{array}{c}5.9 \% \\
(3)\end{array}$ & $\begin{array}{c}8.1 \% \\
(45)\end{array}$ \\
\cline { 2 - 8 } $\begin{array}{l}\text { Total Number } \\
\text { of Appeals }\end{array}$ & 18 & 4 & 17 & 69 & 90 & 51 & 249 \\
\hline
\end{tabular}

* Number of cases with attorneys in parentheses.

We gain from these tables a somewhat different picture of lawyer involvement with the eviction board and changes over time. ${ }^{30}$ Looking only at cases that went to hearing, the 1975-77 period represents in percentage terms the peak of lawyer involvement in the eviction process both at hearings and on appeal.31 Moreover, except for the period 1978-79, when legal representation dipped markedly at both stages, there has been a general diminution over time in the probability that a tenant will have legal help either at the hearing or on appeal. ${ }^{32}$ Had data been available for 1986 and 1987, the

30. One cannot derive Table 1 by combining Tables 2 and 3 because a lawyer might be involved in the same case both at the hearing and on appeal, and lawers were involved in some cases that did not reach a hearing and in other cases only after the appeal.

31. The small number of hearings and appeals during this period means that we cannot make too much of these percentages. But it is safe to conclude that the 1975-77 period does not represent a drop-off in rates of lawyer involvement when the major occasions for lawyer involvement (hearing and appeal) are controlled.

32. The patcern is smoother for appealed cases than for those going to hearing. Controlling for cause of action, the probability of attorney involvement in non-payment cases going to hearing is similar in periods $A$ and $C$ and lower in period $B$, and lower in all three of these periods than in the 
drop-off of legal representation in period $\mathrm{C}$, according to both LASH informants and $C$, would have been greater still.

Note that lawyers often became involved in the eviction process only after the board had voted to evict the tenant. Over the period of the study, attorneys represented tenants at hearings only fifty times. Thus, the actual involvement of attorneys in informal board hearings was substantially less than their apparent involvement in the eviction process; 5 percent of cases going to hearing had a lawyer at or before the hearings, although 9.8 percent of these cases used a lawyer's services at some point in the eviction process. ${ }^{33}$

Tables 1, 2, and 3 only capture the involvement of lawyers in the eviction process when there is a paper trail preserved in the Authority's records. When a tenant consults a lawyer, and the lawyer tells the tenant how to behave before the board or what to say in a letter of appeal but does not write a letter himself or take other steps to represent the tenant, the tenant shows up in our data as unrepresented, although she may have benefitted from legal advice. In recent years especially, it appears that legal aid attorneys often refuse to represent tenants, but give them some advice about what they must do to retain their units (usually pay the rent debt) before sending them on their way. This informal assistance may aid some tenants facing eviction in ways our data do not capture.

Table 4 shows how representation has varied by attorney type over time. ${ }^{3-4}$

first two periods. In income falsification cases there are no lawyers at hearings in any periods with the exception of one case each in periods $A$ and $B$; so there is no meaningful trend. When cases brought for the various other reasons are aggregated, the probability of counsel is similar in periods $A$ and $B$, but lower in $C$. There are no such cases with atorneys in the 1975-77 and 1978-79 periods, but in the former period only two cases fall into this category. The proportion of cases with counsel between 1966 and 1974 is slightly greater than in period C but less than in periods $A$ and $B$.

33. Some attorneys who represented tenants on appeal, particularly before 1980 when appeals might involve de novo hearings, also participated in hearings that were informal in the scnse that the Authority's Commissioners, who judged appeals, were lay persons and basic legal rules of procedure did not apply. Including cases that were docketed but resolved without a hearing, therc were attorneys present at some stage in $8.5 \%$ of the eviction actions.

34. One case with an attorney is excluded from the Table because we could not tell if the attorney was with LASH or was a member of the private bar. 
TABLE 4

\section{Percentage of Cases* By Periods With Atrorneys of DifFERENT TyPES}

PERIOD

\begin{tabular}{|c|c|c|c|c|c|c|c|}
\hline $\begin{array}{l}\text { Percentage } \\
\text { of Cases } \\
\text { Represented: }\end{array}$ & $1966-74$ & $1975-77$ & $1978-79$ & A & B & $\mathrm{C}$ & Total \\
\hline $\begin{array}{l}\text { By LASH } \\
\text { Attornevs }\end{array}$ & $\begin{array}{l}6.7 \% \\
(13)\end{array}$ & $\begin{array}{l}5.0 \% \\
(7)\end{array}$ & $\begin{array}{l}1.7 \% \\
(2)\end{array}$ & $\begin{array}{c}2.5 \% \\
(8)\end{array}$ & $\begin{array}{l}1.7 \% \\
(6)\end{array}$ & $\begin{array}{l}1.3 \% \\
(2)\end{array}$ & $\begin{array}{l}3.0 \% \\
(38)\end{array}$ \\
\hline $\begin{array}{l}\text { By LASH } \\
\text { Paralegal }\end{array}$ & - & - & $\begin{array}{l}2.6 \% \\
(3)\end{array}$ & $\begin{array}{l}5.1 \% \\
(16)\end{array}$ & $\begin{array}{l}3.8 \% \\
(13)\end{array}$ & $\begin{array}{l}4.4 \% \\
(7)\end{array}$ & $\begin{array}{l}3.1 \% \\
(39)\end{array}$ \\
\hline $\begin{array}{l}\text { By LASH. } \\
\text { Type Unclear }\end{array}$ & $\begin{array}{l}1.5 \% \\
(3)\end{array}$ & $\begin{array}{l}.7 \% \\
(1)\end{array}$ & - & - & $\begin{array}{l}.6 \% \\
(2)\end{array}$ & $\begin{array}{l}.6 \% \\
\text { (1) }\end{array}$ & $\begin{array}{l}.6 \% \\
(7)\end{array}$ \\
\hline $\begin{array}{l}\text { Total } \\
\text { LASH }\end{array}$ & $\begin{array}{l}8.2 \% \\
(16)\end{array}$ & $\begin{array}{l}5.7 \% \\
(8)\end{array}$ & $\begin{array}{c}4.3 \% \\
(5)\end{array}$ & $\begin{array}{l}7.6 \% \\
(24)\end{array}$ & $\begin{array}{l}6.1 \% \\
(21)\end{array}$ & $\begin{array}{c}6.3 \% \\
(10)\end{array}$ & $\begin{array}{c}6.6 \% \\
(84)\end{array}$ \\
\hline $\begin{array}{l}\text { Private } \\
\text { Attorney }\end{array}$ & $\begin{array}{c}1.0 \% \\
(2)\end{array}$ & $\begin{array}{l}.7 \% \\
(1)\end{array}$ & $.0 \%$ & $\begin{array}{l}2.5 \% \\
(8)\end{array}$ & $\begin{array}{l}2.6 \% \\
(9)\end{array}$ & $\begin{array}{l}1.9 \% \\
(3)\end{array}$ & $\begin{array}{l}1.8 \% \\
(23)\end{array}$ \\
\hline & S & & 1 & & & & $\mathrm{v}=126$ \\
\hline
\end{tabular}

Bearing in mind that the percentage figures for 1975-77 are deflated relative to those for other periods because of the large number of cases that did not go to hearing, it appears that LASH supervising attorneys were relatively active on behalf of tenants until about 1977, and then their presence diminished dramatically. The drop-off in appearances by LASH attorneys coincides with a major class action victory in a case brought by LASH to secure the Authority's compliance with HUD grievance regulations. ${ }^{35}$ It also seems to reflect a transfer within LASH of responsibility for public housing evictions from its lawyer staff to its paralegals. The two may be related, for once LASH felt that the Authority was complying with the various rules and regulations governing its eviction process, it may have seen the problems of tenants facing eviction as routine matters that could be handled by paralegals. Indeed, LASH apparently designated one paralegal as its specialist in public housing evictions. He was involved in at least nineteen cases arising between 1980 and 1984.

Overall, legal aid handled more than three cases for every case handled by a private attorney; and this is true of every period except $B$, where the ratio is closer to two-to-one. While the proportion of tenants represented by private attorneys is always small, there is a marked increase in that proportion, both

35. See the discussion of the Tilein case in the text accompanying notes 79 through 84 below: 
absolutely and relative to LASH representation, during the 1980's. It is difficult to say why this occurred. It may reflect Reagan era cutbacks in legal services funding and the willingness of some members of the private bar to leap into the breach. It may also reflect the increasing number of LASH alumni who were joining the private Honolulu bar and may have been particularly willing to take eviction cases, for we know that at least some of the private attorneys who represented tenants had had prior legal aid experience. In addition, it may reflect the relative well-being of some tenant families and their desire for real lawyers at a time when LASH was only willing to provide paralegals.

Table 5 relates attorney usage to the reason the Authority sought eviction. ${ }^{36}$

TABLE 5

Lawyer Representation By Cause of Action and Attorney

TYPE 37

CAUSE OF ACTION

Percentage

of All Cases

With Altorneys*

$10.1 \%$

(10)

$26.9 \%$

(14)

$20.9 \%$

(14)

$20.8 \%$

(21)

$9.1 \%$

(1)

$8.6 \%$

Percentage

of Attorney

Cases With

Private Altorneys*

$14.3 \%$

(3)
$28.6 \%$
$(4)$
$30.0 \%$

(6)
$100.0 \%$

(1)

* Number of cases in parentheses.

36. When more than one lease violation was charged, we coded cases involving non-payment and a behavioral charge by the behavioral charge because we felt that the Authority would ordinarily not take the trouble to prove the behavioral charge if it were certain it could evict for non-payment. Where more than one behavioral violation was charged one of the violations always involved "Other Trouble" while the other involved falsification, guests, or pets. Sep infra note 37 for category definitions. We coded these cases into whichever of the three more specific categories applied. All told 118 of 1261 cases involved multiple charges, and in 74 of these cases non-payment was the only other violation.

37. "Non-payment" ("NP") is failure to pay rent; "Falsification" ("Fals.") involves not reporting or misreporting income at the annual examination used to determine the next year's rent; "Guests" involves letting unauthorized persons live in the unit; "Pets" involves keeping animals-almost always dogs-in violation of Authority rules; "Other Trouble" ("OT") includes other troublesome behavior such as fighting, unsanitary housekecping, or parking inoperable vehicles, and "miscellaneous" ("Misc.") includes other, often technical, lease violations such as the refusal to transfer to a proper size unit.

In one case in the OT category we know that the tenant had an attorney but do not know if the attorncy came from legal aid or was privately retained. We omit this case when we calculate the percentage of represented $O \Gamma$ tenants with private attorneys and the overall percentage of represented tenants with private attorneys. 
Looking at the second row in Table 5 we see a suggestion of a wealth effect in the fact that 14.6 percent of those tenants charged with non-payment of rent who were represented by a lawyer had a private attorney compared with 25 percent of those charged with behavioral violations. ${ }^{38}$ Moreover, private attorneys account for 30 percent of the attorneys representing tenants charged with income falsification, the offense that is most suggestive of higher than average income. ${ }^{39}$

Looking at the first line of Table 5, we see that tenants are substantially less likely to have attorneys in cases brought for non-payment of rent than they are in cases where guests, pets, or what we call "other trouble" behavior is charged. ${ }^{40}$ The rate of attorney usage is intermediate for income falsification, although closer to the pattern in non-payment cases. The rate for miscellaneous lease violations is like that for falsification, but there are so few cases in this category that there is no point in attempting an explanation.

The difference between non-payment cases and behavioral violations is striking. It must represent differences in the propensity of tenants facing eviction to seek out lawyers and/or differences in the propensity of lawyers to take on clients. In particular, since so many tenants are represented by legal aid and can afford no other attorneys, the pattern may reflect LASH policies of selective representation.

We think that both tenants, in their propensity to seek out attorneys, and attorneys (particularly LASH attorneys), in their propensity to take on clients, respond to the same considerations. These are that non-payment of rent cases are ordinarily open and shut on the facts and raise no great value issues. ${ }^{11}$ Pet cases, by contrast, are often seen-by tenants especially-to raise important value issues, ${ }^{42}$ and guest and other trouble cases are often hotly disputed on the facts. Thus, in the eviction setting, lawyers tend to

38. These include guests, pets, and other trouble. See supra note 37.

39. Usually when tenants conceal income it is income from some source other than the principal wage carner's full-time eamings. Common sources of concealed income are second jobs, a spouse's earnings, and part-time or temporary employment. The amount saved in rent from concealing income is often in the range of a thousand dollars or more, and there are cases in which it has been in excess of $\$ 5,000$. This will depend on the amount concealed and the length of time it goes undiscovered.

40. This is true of all the time periods except 1975-77 and 1978-79. In the former period only four cases involving these offenses reached the hearing stage, and in the latter period, attorney usage, for reasons we cannot identify, was low for all causes of action.

41. Income falsification cases tend to be similar in these respects, although in some cases there is a genuine question about whether a tenant realized that a certain type of income had to be reported.

42. Justifications that would appeal to middle-class values were more common in such cases than in those brought for other reasons. The most common justification was that a dog was kept for security reasons. The most compelling justification we encountered was offered by a grandmother who said that a pet was necessary for the psychological well-being of her young grandson (whom she was raising). The grandmother's claim was supported by a social worker and by school reports stating that when she had temporarily removed the dog her grandson's behavior had markedly deteriorated. Nevertheless the Authority and the board refused to allow her to keep the dog, and the grandmother moved to avoid depriving her grandson. 
appear for tenants when it seems that their special skills will make a difference. ${ }^{+3}$ Our data do not allow us to distinguish between tenant self-selection and attorney selection in explaining this association, but LASH interviewees reported that in recent years they counseled but refused to represent most non-payment tenants who approached them for aid. They felt, correctly, that if the tenant could pay her back rent she would be allowed to stay regardless of their involvement, and if she could not pay her back rent there was nothing they could do. As a result, in periods $B$ and $C$ combined, lawyers appear in only about 1 percent of the non-payment cases heard by the eviction board, and in only about 5 percent of non-payment appeals. During the same two periods 17.5 percent of the sixty-three tenants charged with guests, pets, or other trouble behavior had a lawyer's aid at or before their first hearing, and 40.9 percent of the twenty-two people who appealed evictions on these counts had a lawyers's assistance on appeal. ${ }^{44}$

We have looked thus far at some simple statistics describing the role that lawyers play in the eviction process. ${ }^{45}$ We see that, although the eviction process was designed to proceed without lawyers and largely did so during the first decade of its existence, since the coming of the federally funded legal aid program to Oahu, lawyers have been regular if infrequent participants in the Authority's eviction process both at hearings and on appeal. Legal aid attorneys account for the bulk of the representation, but private attorneys represent tenants as well, particularly in cases other than non-payment. We have no way of knowing what proportion of private attorneys in our study were working on a pro bono basis, but in the case files several statements from private attorneys indicate that they were working pro bono, and other statements from other private attorneys indicate that they were being paid for their services-sometimes by noting that expected payments had not been made. We also observed a number of cases in which private attorneys were involved only to the extent of writing a letter or making a phone call-behavior usually associated with low-fee or no-fee representation. ${ }^{46}$

43. The relationship between lawyer involvement and case type is similar at the hearing and on appeal except in the case of income falsification appeals. I awvers were present at or before the hearing in $2.3 \%$ of non-payment cases: $2.5 \%$ of falsification cases: $22.7 \%$ of guest cases: $14.5 \%$ of pet cases; and $16.0 \%$ of cases involving other trouble behavior. Considering only those cases appealed, lawyers were involved in $9.1 \%$ of non-payment appeals; $26.1 \%$ of falsification appeals; $38.5 \%$ of guest appeals; $36.4 \%$ of pet appeals; and $54.2 \%$ of appeals in cases involving other trouble behavior.

44. However, all of the latter instances of lawver use were in period $B$. In period $C$ none of the seven tenants who appealed on these counts had a lawer to assist them. This may be because at the outset of period $C$ the Authority's Commissioners delegated to the Executive Director the responsibility of determining if there were new facts and evidence sufficient to justify an appeal. Ihis meant that an attorney appealing such a case could not appear before the Commissioners to argue that the appeal should be heard, but could only petition the staff. Attorneys may have felt that in these circumstances there was little they could do to help tenants.

45. We are currently working on a paper that will explain with the aid of multivariate models the likelihood that tenants will have attomeys and the effects of representation on delay and outcomes.

46. Lochner, The No Fep And Low Fep Legal Practice Of Private Allormeys, 9 Law \& Soc'Y RnV. 431. $455-59(1975)$. 
The involvement of lawyers in the eviction process changed over time. Lawyer involvement both at the hearing and on appeal was, for some reason we cannot identify, sharply down in 1978-79, the period following LASH's greatest triumph, and then again diminished after 1982 in the periods we have labeled B and C. Beginning in period A (from October 1979) and continuing through periods $\mathrm{B}$ and $\mathrm{C}$, private representation, while never high, is, both as a proportion of all cases and in relation to LASH representation, about twice what it had been in the prior fourteen years. We will offer some possible explanations for these patterns later in this article, but they are quite speculative.

We feel we are on somewhat firmer ground when we look at the kinds of cases in which attorneys appeared. Attorneys were relatively unlikely to appear in non-payment cases and much more likely to appear when the charge involved sheltering unauthorized guests, keeping pets, or engaging in other trouble behavior. We believe this is because neither tenants nor attorneys see much of a role for lawyers when an open and shut violation of a generally accepted rule is alleged. Tenants want attorneys and attorneys are willing to represent tenants before informal tribunals when cases present conflicting factual allegations or otherwise pose issues similar to those posed in ordinary contested litigation.

\section{VII}

\section{IsSUes of STYle}

Now we shall turn our attention to the ways in which attorneys represent tenants before informal tribunals. We were able to identify three distinct styles. The first we call legalistic. It involves an attempt to impose legal rules on the tribunal. The rules may be procedural or substantive but are often the former, as when a lawyer at the hearing objects to evidence as if he were in court or moves for a dismissal before the hearing because the tenant's notice of the Authority's intention to evict did not meet a statutory deadline. The second is what we call tenant style. Lawyers employing this style make the same kinds of arguments that unrepresented tenants might make or encourage tenants to do the same things-like paying back rent-that unrepresented tenants often do if they wish to remain in housing. The third we call the service style. Lawyers employing this style use their professional skills to help tenants deal with agents, other than the Authority, that either have contributed to a tenant's current situation or can help her escape it. The service most frequently encountered was helping tenants secure money from welfare agencies to pay the rent. Other services include filing for bankruptcy to help tenants cope with debts and securing peace bonds or similar restraining orders against violent ex-spouses whose project visits have motivated the Authority's decision to evict.

While the legalistic and tenant styles suggest distinct attitudes toward the usefulness of law, the service style is a melange. The services that lawyers perform for tenants often involve arguing legalistically or otherwise 
manipulating the law, but once these services have been accomplished, argument to the board usually follows the tenant style. Often a strong tenant style argument can be made because the lawyer's service has given the tenant the wherewithal to correct the lease violation or gives the board a special reason to accept the tenant's promise to cure the violation and not relapse in the future.

Table 6 presents the basic breakdown of lawyer styles by period, and Table 7 breaks down style by cause of action. ${ }^{47}$ We see from Table 6 that the tendency to resort to the tenant style appears to have increased markedly beginning in period $\mathrm{A}$ when the Authority reorganized its eviction processes by appointing a full-time eviction specialist and a second eviction panel. It was also in this period that the statute establishing the eviction board was amended, and rules regulating the board's procedures were adopted in accordance with the Hawaii Administrative Procedure Act. ${ }^{48}$ At the same time, the utilization of the service style, which accounts for a high proportion of the cases between 1975 and 1979 but never a large number, falls off. To some small extent, this increased tendency to use a tenant style may be due to the fact that LASH paralegals appeared in only three cases before period A but in thirty-six cases afterwards, and they seem somewhat more likely than LASH supervising attorneys to use a tenant style. ${ }^{49}$ But this cannot be the whole story, for looking only at cases handled by supervising attorneys, we see a marked change with $A$ 's arrival. Before period A, LASH attorneys used a legalistic style in 64.7 percent of the seventeen cases for which we have style data and a service style in an additional 17.6 percent of their cases. Beginning with period A, LASH attorneys used a legalistic style in 42.9 percent of the fourteen cases we could code and a service style in one additional case or 7.1 percent. Thus, these attorneys made tenant style pleas in only 17.6 percent of their cases before $A$ 's arrival on the scene but in 50 percent of the cases that they handled afterward.

One possible explanation for this change in representational style is that the presence within the Authority of a full-time eviction specialist or other changes concomitant with $A$ 's arrival meant that the Authority's eviction

47. About a quarter of our lawver cases did not contain sufficient information to allow us to identify attorney styles.

48. Haw. REv. STAT. $\$ \$ 91-1$ to $91-18$ (1985).

49. During the last three periods LASH paralegals appeared in 31 cases for which we have information on style. They employed a legalistic style $32.2 \%$ of the time, a service style $6.5 \%$ of the time, and a tenant style $61.3 \%$ of the time. During this time LASH supervising attorneys handled 14 cases. They employed a legalistic style $42.9 \%$ of the time, a service style $7.1 \%$ of the time (one case), and a tenant style $50 \%$ of the time. Private attorneys participated in 15 cases during the last three periods. They used a legalistic style $33.3 \%$ of the time, a service stvle $26.7 \%$ of the time, and a tenant style $40 \%$ of the time. Before period A. I.ASH supervising attorneys constituted almost all of the lawyer participants. During this time 17 of the 21 lawyer cases for which we have information on style involved I.ASH supervising attorneys, three involved LASH paralegals, and one involved a private attorney. In one lawyer case in period A we do not know the lawver lype and in one period $B$ case we know the lawyer came from I.ASH but we do not know if he was a supervising attorney or a paralegal. In both these cases the attoney used a legalistic style. They are not included in the above figures. 
TABLE 6

Styles of Representation By Period*

\begin{tabular}{|c|c|c|c|c|c|c|c|}
\hline \multirow[b]{2}{*}{ LAWYER STYLE } & \multicolumn{7}{|c|}{ PERIOD } \\
\hline & $1966-74$ & $1975-77$ & $1978-79$ & $\mathrm{~A}$ & $\mathrm{~B}$ & $\mathrm{C}$ & Total \\
\hline Legalistic & $\begin{array}{c}72.7 \% \\
(8)\end{array}$ & $\begin{array}{l}40.0 \% \\
(2)\end{array}$ & $\begin{array}{c}20.0 \% \\
\text { (1) }\end{array}$ & $\begin{array}{c}33.3 \% \\
(10)\end{array}$ & $\begin{array}{c}45.5 \% \\
(10)\end{array}$ & $\begin{array}{c}30.0 \% \\
(3)\end{array}$ & $\begin{array}{c}41.0 \% \\
(34)\end{array}$ \\
\hline Service & - & $\begin{array}{l}40.0 \% \\
\quad(2)\end{array}$ & $\begin{array}{c}60.0 \% \\
(3)\end{array}$ & $\begin{array}{c}16.7 \% \\
(5)\end{array}$ & $\begin{array}{l}4.5 \% \\
\text { (1) }\end{array}$ & $\begin{array}{l}10.0 \% \\
\text { (1) }\end{array}$ & $\begin{array}{c}14.5 \% \\
(12)\end{array}$ \\
\hline Tenant & $\begin{array}{c}27.3 \% \\
(3)\end{array}$ & $\begin{array}{l}20.0 \% \\
\text { (1) }\end{array}$ & $\begin{array}{l}20.0 \% \\
\text { (1) }\end{array}$ & $\begin{array}{c}50.0 \% \\
(15)\end{array}$ & $\begin{array}{c}50.0 \% \\
\text { (11) }\end{array}$ & $\begin{array}{l}60.0 \% \\
\quad(6)\end{array}$ & $\begin{array}{c}44.6 \% \\
(37)\end{array}$ \\
\hline Total Cases & 11 & 5 & 5 & 30 & 22 & 10 & 83 \\
\hline
\end{tabular}

* Number of cases in parentheses.

\section{TABLE 7}

Styles of Representation By Cause of Action

CAUSE OF ACTION

LAWYER STYLE

L.egalistic

\begin{tabular}{ccccccc} 
NP & Fals. & Guests & Pets & OT & Misc. & Total \\
\hline $23.7 \%$ & $40.0 \%$ & $72.7 \%$ & $55.6 \%$ & $50.0 \%$ & $100.0 \%$ & $41.0 \%$
\end{tabular}

(9)

(4)

(8)

(5)

(7)

(1)

Service

\begin{tabular}{ccccccc}
$\begin{array}{c}23.7 \% \\
(9)\end{array}$ & - & $\begin{array}{c}9.1 \% \\
(1)\end{array}$ & - & $\begin{array}{c}14.3 \% \\
(2)\end{array}$ & - & $\begin{array}{c}14.5 \% \\
(12)\end{array}$ \\
\hline $\begin{array}{c}52.6 \% \\
(20)\end{array}$ & $\begin{array}{c}60.0 \% \\
(6)\end{array}$ & $\begin{array}{c}18.2 \% \\
(2)\end{array}$ & $\begin{array}{c}44.4 \% \\
(4)\end{array}$ & $\begin{array}{c}35.7 \% \\
(5)\end{array}$ & - & $\begin{array}{c}44.6 \% \\
(37)\end{array}$ \\
\hline 38 & 10 & 11 & 9 & 14 & 1 & 83 \\
\hline
\end{tabular}

* Number of cases in parentheses.

processes attended more closely to matters of legal form and so left less room for legal challenges. ${ }^{50}$ Another possibility is that attorneys became more accepting of the Authority's procedures. This may reflect both the Authority's greater attention to legal form and the increasing number of cases that LASH represented once the Authority's pace of evictions increased. More regular representation may have allowed LASH's attorneys and paralegals to develop working relationships with the Authority's hearing officer. ${ }^{51}$

50. Examination of changes over time in lawyer style, controlling for the cause of action, indicates that the style changes we have identified cannot be explained by changes in the mix of case ypes over lime.

51. This does not explain the fact that private attornevs were legalistic in only a third of the ases they handled, but since, with one exception, private attorneys are only involved in evictions from period $A$ on, we cannot establish an carlice private attorney bascline. 
Table 7 indicates that the tenant style was more common in non-payment and falsification cases than in cases brought for other causes of action. This, we hypothesize, is a function of the more or less open and shut nature of these cases and the legitimacy of the rules they sanctioned. In non-payment cases the tenant style was to promise to pay or, in the later periods, actually to pay the rent owing. In falsification cases the usual tenant style was to argue that reporting requirements had been misunderstood. Service style representation is highest in non-payment cases because the services that lawyers were best situated to perform involved aiding tenants in acquiring money or managing their debts. The intermediate rate of tenant style representation in other trouble cases and pet cases suggests that lawyers tried to excuse their client's behavior ("the neighbors started the fight") or made promises of reform ("my client will give her dog away") more often than they contested the legal validity of the Authority's evidence or challenged the rule on which the Authority relied.

If we contrast cases that had a lawyer only at the pre-hearing or hearing stage with those that had a lawyer only on appeal, we find that the legalistic and service styles were somewhat more common at the hearing. One of these styles was used in fourteen of twenty-six cases that only had lawyers at the hearing compared to twelve of thirty cases that only had representation on appeal. This suggests that there may have been more room for legal maneuvering to aid tenants at hearings than there was on appeal. ${ }^{52}$

Finally, we can look at the relationship between legal representation, lawyer style, and outcomes. Table 8 takes a step in this direction. ${ }^{53}$ It aggregates subjective judgments about whether attorneys affected case outcomes $^{54}$ and relates this information to lawyer style. The Table only

52. In 12 of 16 cases in which a lawyer represented a tenant at both the hearing and on appeal, the legalistic or service style was employed, as it was in seven of the 10 cases in which the lawyer's involvement began after the appeal had been heard. The latter often involved taking the Authority to court, for no official internal remedies remained. In both these situations service style representation was less common than it was when representation was only at the hearing or only on appeal. We are, of course, not talking about large numbers of cases.

53. As we indicate in note 45, supha, we have begun exploring, in a multivariate framework, the effects of having a lawyer on case outcomes. Here we simply summarize subjective judgments, based on case records, of whether lawyers made a difference in the cases of those they represcnted. and, if so, whether they helped or hure their clients. The multivariate analysis is not yet to the point where we can sav whether what we are finding is consistent with what we report here.

54. These judgments are the first author's and based on often fragmentary case files. In about $20 \%$ of the cases no judgment could be reached because of insufficient information. We say that a lawver made a difference if the board's decision or the duthority's action on appeal or even afterward secms to have responded to arguments that unrepresented tenants were not likely to have made. We also say that representation made a difference if the lawyer made, and the Authority responded 10 . a tenant style argument that the tchant probably would not have been able to make had she not had legal help (as when a service-oriented attorney solves a welfare problem for the tenant, which provides her with money to clear her rent debt) or that the Authority would have been unlikely to respond to had the argument not been made by a lawer. We say that a lawyer did not make a difference where the result appears 10 be one which an unrepresented tenant would have obtained. If there is no special indication of a lawyer effect, we assume that, if the result is the routine board disposition for cases of that lype at that time, there was no effect. In some cases we are unsure about whether a disposilion is routine or whether certain information should be taken as an indication of a lawver cliect. We code these ases as cases in which the presence of an attorney "perhaps" had an 
includes information on cases in which the tenant was allowed to stay after the hearing, appeal, or post-hearing plea. In twenty-nine attorney cases in which the tenant was either evicted or vacated without a board decision, there is no case in which it appears that a lawyer's actions denied the tenant a likely victory, and there are only two cases in which the lawyer's representation is such that it appears that the tenant might have been better off had she done without it. In short, if our judgments are accurate, legal representation virtually never hurt tenants. When represented tenants were evicted, one may almost always conclude that they would have fared no better on their own.

Table 8 indicates that in twenty-three cases-or 41.8 percent of the cases in which represented tenants were allowed to stay-we are reasonably confident that they would have left or been evicted but for the aid they received from counsel. In an additional fourteen cases-or 25.5 percent of these cases-legal representation may have made a difference. In 32.7 percent of the cases it appears that the tenants would have been allowed to stay whether or not they had had an attorney.

Not surprisingly, among the cases in which the tenant succeeded in staying, lawyers were most likely to have made a difference when legalistic arguments were advanced. These were arguments that required knowledge that tenants did not have, so that when the board or Authority responded to such an argument by allowing the tenant to stay, it seems likely that the lawyer's presence was crucial to the Authority's decision. ${ }^{55}$ This is not to say that legalistic arguments are the most effective kinds of arguments that lawyers make. Lawyers advanced legalistic arguments on behalf of about a third of the tenants allowed to stay but made such arguments in $\mathbf{5 4 . 2}$ percent (thirteen of twenty-four) of the stylistically classifiable cases in which the tenant left or was evicted.

effect. But even when we code "Yes" or "No" in response to the question of whether a lawyer had an effect, we are talking in probabilistic terms.

55. The difficult issue for coding is whether the decision to allow a tenant to stay was overdetermined. Thus, if a non-payment tenant paid back all her rent and was allowed to stay by the board after her lawyer made a legalistic argument. we would code the case as one in which the lawyer made no difference. On the other hand, if as happened in one case, the tenant paid back her rent after her appeal and the lawver had to go to court to stop the eviction, we coded the case as one in which the lawyer made a difference. If by objecting to a legally deficient notice the lawyer succeeded in delaying an eviction action for several months during which time the tenant was able to secure money to pay her rent, our coding of the case depended on what information we had about the likelihood that the tenant would have come up with the money had there been no delay. In the absence of information about these prospects, we treated such cases as cases in which the lawyer perhaps made a difference. If the lawyer pretermitted the eviction process as when a lawyer objected to the absence of a witness and the Authority cancelled a hearing without rescheduling it, we assumed the lawyer made a difference even though we could not know what would have happened at the hearing had it been held. In this sense, our estimate of when lawyers made a difference should be taken as a maximum estimate. We are conservative in saving that lawyers had no effect. We are similarly conservative in that we coded cases where the lawyer helped secure a conditional deferment as cases in which the tenant stayed and the lawver made a difference, even if the tenant subsequently defaulted on conditions that had been set and vacated or was evicted. We did this because, despite the fact that the tenant ultimately left housing. the lawyer helped the tenant secure a positive outcome that she would not have secured on her own. Five of the 23 cases $(21.7 \%)$ in which the lawyer made a difference fell into this category as did one of 14 cases in which the lawyer perhaps made a difference. 
TABLE 8

An Evaluation of Whether lawyers Make a Difference By LAWYER STYLE*

DID LAWYER MAKE A DIFFERENCE?

\begin{tabular}{lcccc} 
LAWYER STYLE & Yes & Perhaps & No & Total \\
\hline Legalistic & $\begin{array}{c}75.0 \% \\
(15)\end{array}$ & $\begin{array}{c}15.0 \% \\
(3)\end{array}$ & $\begin{array}{c}10.0 \% \\
(2)\end{array}$ & $\begin{array}{c}100 \% \\
(20)\end{array}$ \\
\hline Service & $\begin{array}{c}50.0 \% \\
(5)\end{array}$ & $\begin{array}{c}40.0 \% \\
(4)\end{array}$ & $\begin{array}{c}10.0 \% \\
(1)\end{array}$ & $\begin{array}{c}100 \% \\
(10)\end{array}$ \\
\hline Tenant & $12.0 \%$ & $28.0 \%$ & $60.0 \%$ & $100 \%$ \\
& $(3)$ & $(7)$ & $(15)$ & $(25)$ \\
\hline Total & $41.8 \%$ & $25.5 \%$ & $32.7 \%$ & $100 \%$ \\
& $(23)$ & $(14)$ & $(18)$ & $(55)$ \\
\hline
\end{tabular}

* Number of cases in parentheses.Includes only cases represented by a lawyer where tenant was allowed to stay in housing.

The service style approach, like the legalistic style, appears to have been often instrumental in aiding tenants allowed to stay. In only one of the ten service style cases in which the tenant was allowed to stay are we reasonably confident that the outcome would have been the same had the attorney not been involved in the action, and in five of the ten cases it appears likely that the outcome would have been different. In the remaining four cases it is difficult to say whether the lawyer's presence was important. These were cases in which the tenant might have accomplished for herself what her lawyer provided, or in which the board might have let the tenant stay without the extra guarantees the lawyer was able to offer. The service style is more prevalent when tenants stay than when they leave. It was used in 16.9 percent of the former cases and 8.3 percent of the latter.

Among the group of cases in which tenants are allowed to stay, the tenant style is least likely to appear to have mattered. This too is not surprising because tenants ordinarily make such arguments on their own behalf. Our judgment was that 60 percent of the successes associated with tenant style arguments involved situations in which unrepresented tenants commonly made similar arguments to the same effect. In three cases, or 12 percent of the total, it appeared that a tenant's argument would not have succeeded where a lawyer's argument did. For example, after a tenant's appeal had been rejected, one lawyer wrote a personal letter to an Authority official raising what he acknowledged were non-legal considerations, and the tenant was given a second chance. Seven cases were difficult to classify because, while the arguments were of a kind a tenant might have made, it was not clear that the board or the Authority would have bought the arguments had they not been made by an attorney. For example, in arguing that a tenant's debts would not interfere with future rent payments, an attorney might note 
specifically how each debt could be managed while a tenant might simply assert that they could be handled. In the later time periods it is difficult to say whether a board that accepted the attorney's argument would have been satisfied with the tenant's vaguer assertion. Had the case arisen in 1970, however, it would have been clear that the representation made no difference and the case would have been coded this way.

Overall, the tenant style argument is relatively successful. It accounts for 47.5 percent of the arguments advanced in cases in which tenants were allowed to stay but only 37.5 percent of the arguments in cases in which tenants left or were evicted. However, this largely reflects the availability of this argument whenever a non-payment tenant paid back her rent debt, and the Authority's general willingness to allow tenants to stay in these circumstances.

These data indicate that lawyers can make a difference in informal tribunals like the public housing eviction board we have examined. However, we started with 1268 cases. In only twenty-three cases, or 1.8 percent of the total, does it appear that the presence of an attorney helped the tenant, and in only an additional 1.1 percent of the cases do we feel that we cannot exclude that possibility. What do these figures mean? If we extrapolate from the data we have to 100 percent representation, it appears that lawyers would have aided tenants about 29 percent of the time, and they would perhaps have aided them in an additional 18 percent of the cases. ${ }^{56}$. These figures suggest that despite the informality of the Authority's eviction process, many tenants would have fared better had they been able to retain legal counsel. But one cannot extrapolate from the group of tenants who had attorneys to the group of unrepresented tenants in this fashion. We are confident that the number of unrepresented tenants in our sample who would have been helped by an attorney does not approach 47 percent or even 29 percent of the total number of tenants who lacked counsel.

Consider first that a majority of unrepresented tenants have, over the years, prevailed before the board or on appeal, and so did not need an attorney to secure a favorable outcome. Second, recall that another substantial group-amounting to more than 8 percent of the total-vacated before the first hearing. ${ }^{57}$ Many of these are likely to have had hopeless cases. Third, of those who were evicted at the first hearing and then vacated or unsuccessfully appealed, about 70 percent were charged with non-payment of

56. We extrapolated by assuming that when a tenant stayed and we could not determine whether a lawyer had made a difference, the probability that the lawyer made a difference was $41.8 \%$ and the probability that the lawyer might, perhaps, have made a difference was $25.5 \%$. Spe Table 8 . We then calculated the number of additional cases that these percentages represented, added these numbers to the totals for the "yes" and "perhaps" cases in Table 8 and divided by 107, the total number of lawyer cases for which we had outcome information. For the reasons mentioned in note 55, this figure is a maximum estimate. Our coding conventions may be added to the list of reasons given in the text below for concluding that this extrapolation is a substantial overestimate of the degree to which lawyers might have helped the group of unrepresented tenants.

57. lenants who attend board hearings and are eventually evicted or vacate constitute about $20 \%$ of the docket cases in our sample. 
rent. Except where attorneys might have identified sources of funds that the tenants could not have acquired on their own, legal representation is unlikely to have helped these tenants. Fourth, attorneys are not always successful. Represented tenants are evicted about a third of the time, and even when represented tenants stay, about 36 percent of the time the representation appears to have made no difference, ${ }^{58}$ and in another quarter of the cases it may not have been crucial. Fifth and most important, represented cases have been selected by the tenants involved, and often by the attorneys as well, as cases in which a lawyer's presence seemed useful. Thus, the unrepresented tenants would not have found lawyers as useful as did those who in fact acquired them. While we cannot know the proportion of cases that would have turned out differently if all tenants had lawyers, that proportion may well be quite small. 59

\section{VIII}

\section{Changes over Time}

One recurring theme in the data we have presented is that the relationship of attorneys to the eviction process changed over time. We can better understand these changes with information gleaned from case records and interviews that we cannot quantify. The story these materials allow us to tell largely concerns legal aid's involvement with the Authority, for private attorneys were rarely involved with evictions until period $A$, when the transformation of the Authority's procedures and of lawyers' reactions to them was well under way. When private attorneys did get involved, their ways of representing tenants were, so far as we can determine, not very different from that of their legal aid counterparts, but one sees proportionately more private attorney cases in which representation appears to be confined to one or two letters or phone calls.

58. This figure is not inconsistent with Table 8 , for it includes cases for which we have no style information.

59. Note also that the Authority can react to stcps that tenants take to avoid eviction. If represented tenants often prevailed at hearings, the Authority would probably have taken steps to diminish their success rate unless that success were due to non-payment tenants repaying their rent. Some of the changes the Authority secured in the statute establishing the board and in its own rules and regulations were almost certainly designed in part to make its eviction system less vulnerable to legal challenge and thereby reduce the success rate of legalistic arguments.

Although for this reason and those we discuss in the text it is unlikely that more widespread representation would have made a great difference in the outcomes tenants received, preliminary examination of data that we do not present here suggests that there is one difference that is strongly associated with legal representation: delay. Cases with lawyers take longer to resolve than those without them. When lawvers get involved in eviction action, continuances are almost always requested and are usually granted. Delays may also occur when negotiation is ongoing. Delay is ofien valuable for tenants because it gives them more time in low-rent public housing and more time lo scarch for other accommodations. 
IX

The Atrorney's Perspective: 1966-74

The federally funded legal aid program, LASH, arrived in Hawaii in 1967 as part of the Johnson Administration's War on Poverty. By 1970 the Authority was well aware of LASH, as LASH attorneys took on the cases of a few tenants threatened with eviction and worked with other public housing tenants to organize a tenants' union and to lobby for the inclusion of two tenants on the eviction board. LASH's organizing efforts quickly bore fruit, for the Authority's staff encouraged rather than resisted their initiatives. As the first LASH director of law reform recalls:

They [the head of the Authority and his official superior, the head of the Department of Social Services] were virtually impossible to organize against because they were completely affable and very friendly . . . very reasonable.

In contrast to this evaluation of the Authority's leadership are the recollections that various LASH attorneys who handled cases between 1969 and 1974 had of the eviction board and its hearing process. One attorney, when asked about the Authority's eviction process and the quality of the eviction board, remarked:

[I]t was a nightmare. There wasn't any due process; there was no notion that people were allowed to have due process .... [T] angry at us for attempting to assert anybody's rights because it had never happened beforc. ${ }^{(6)}$

Another attorney, when asked about due process during this period replied, "There wasn't any." A third, who at one time was the head of LASH, identified as major due process problems during 1974-75, "[n]otice, right to representation, types of enforcement of federal regs." When asked what legal aid attorneys thought of the board from a pure fairness standpoint, he replied that it was characterized by "lack of professionalism [and] knowledge," but noted that the board improved toward the end of his tenure. In fact, at the start of this director's tenure tenants charged with non-payment were virtually never evicted at initial hearings, but by the end of this lawyer's tenure they were evicted about one-quarter of the time."il Tenants, in short, did better during the "nightmare" period than they were ever to do again.

Moreover, it is not clear that the Authority's eviction process during this period should be labeled a nightmare from a due process perspective. This characterization appears to reflect the standpoint of a lawyer with an expansive view of due process and an expectation of something like courtroom procedure more than it does the state of the law. The board's procedures, it appears, always met the minimum requisites of due process as

60. The project managers regarded this chairman with equal disapproval. To them he was a "blecding heart" who always sided with the tenant.

61. The proportion of evictions in cases brought for reasons other than non-payment did decrease somewhat during this director's tenure, but there were so few such cases that not much can be made of this. 
enunciated in the leading opinions of the day. ${ }^{62}$ Tenants received notice of the Authority's charges; they had a right to counsel; they could hear the case against them; they could introduce evidence; they could cross-examine witnesses; and they had the benefit of an independent decisionmaker that was not only purportedly neutral but was in fact often sympathetic to their needs and concerns. In the welfare area due process has not required more. Indeed, while LASH attorneys do not recall the pre-1975 eviction board with fondness, they agree that when it came to evictions, public housing tenants were better off than their counterparts in private housing who faced judicial summary eviction. One reason they give for the small number of public housing cases that LASH handled during this period is that the situation of impoverished tenants in private housing was far more desperate.

The interesting question is why these lawyers so misevaluated the implications of the board's informality for the interests of the client population they wished to protect. We believe there are several reasons. The first is that LASH attorneys appeared before the board only rarely. Since they were not repeat players, they did not appreciate the overall pattern of board decisionmaking. The second is that LASH attorneys appeared in tenantselected actions. Thus, tenants who had more complex cases, who were standing on issues of principle, ${ }^{63}$ or who had the greatest fear of being evicted-in short tenants charged with offenses other than non-paymentwere more likely than other tenants to be represented by legal aid. These were the tenants who were most likely to be evicted during the period 196674 regardless of representation. Had LASH attorneys represented a random sample of tenants brought before the board during this period, they might have recognized the generally lenient pattern of board dispositions. ${ }^{64}$ The third reason is that the LASH attorneys were professionally trained to see certain features as crucial to fair adjudication. ${ }^{65}$ The absence of these features triggered in the professionally trained mind the conclusion that the board was unfair. Particularly important was the absence of familiar procedural rules and the frustration this absence engendered.

The following interchange, for example, comes from a case that the board heard in 1969. It shows a LASH attorney attempting to impose a legalistic model-rules of evidence-on the board's proceedings. The case involved a 59 -year-old woman, Mrs. $Y$, who because of a disability had been placed in a high-rise apartment building for the elderly. Her drinking, cursing, and frequent male guests led to a series of complaints by the neighbors and

62. See Goldberg v. Kelly, 397 U.S. 254 (1970): Thorpe v. Housing Authority of the City of Durham. 393 U.S. 268 (1969).

63. These seem to have been true largely in "pet" actions. One tenant, for example, had given his dog away before the board hearing, but did not reveal this to the board until after his hearing had concluded and the board had voted to evict him.

64. This explains why the LASH attorneys and the project managers could be equally harsh in their judgment of the board during this period. Managerial judgments were based on large samples of board actions in which non-payment cases predominated.

65. Even if these features were not essential to fair adjudication, they were for lawyers symbolic cues of fairness. Cf. E. Goffman, Frame Anatsisis ch. 3 (1979) (discussing the concept of keying). 
ultimately to an attempt to evict her. Because the tenant had a LASH attorney who signaled through pretrial motions his intent to proceed legalistically, the Authority arranged to have the state assign it a Deputy Attorney General ("DAG") for the hearing. ${ }^{i 6}$ At one point the DAG attempted to introduce records of complaints the project manager had received about the tenant. The DAG, too, had the rules of evidence in mind. Although her understanding of what they entailed was not as good as her opponent's, she prevailed because the board was informal; its non-lawyer chair was both unwilling and incapable of making a legal ruling on the matter. ${ }^{67}$ The following is a portion of a dialogue that occupied more than three legal-size transcript pages. It began with the DAG questioning the project manager and establishing that certain records he had with him were records of complaints he had received about the tenant.

DAG: $\quad$ Are the entries made in the regular course of business in the office?

MANAGER: Yes, they are.

DAG: I submit for evidence, Mr. Chairman, the records in the file of Mrs. Y, being the records of [project], showing the daily entries or the entries made in respect to Mrs. $Y$.

LASH: $\quad$ Mr. Chairman, I've got some problems here. May I ask the purpose for which the records are being submitted?

DAG: We wish to show the history and complaints made and entered into by [project] and I have here Section 6-225 of the Hawaii Revised Statutes and I'll give you a copy of the Section of the Statutes pertaining to business records as being an exception to the hearsay rules.

LASH: Mr. Chairman, I don't have any difficulty with facts that those records are what Mr. [Manager] and his staff have written down and if it is admitted for the purpose of showing there have been complaints, I don't have any difficulty with that. I would like to be very clear that these records should not be taken as a reference to indicate the truth or falsity of anything in any complaint.

66. We have no way of knowing whether the Authority would have sought to present its case through an attorney if the LASH attorney's pretrial behavior had been confined to informal requests for information and not included formal motions to dismiss, to inspect evidence, and for a more definite statement of the charges.

67. In fact the DAG should have prevailed because the eviction board was not bound by judicial rules of evidence. But the debate proceeds-except for one brief moment-as if these rules should be followed. 
$\circ$

DAG: Mr. Chairman, we submit that these records are an exception to the hearsay rules pursuant to Section 622-5, Hawaii Revised Statutes as being entered in the duty records in the regular course of business. Mr. [Manager], would you please read to the Board the entry for April 2, 1969, in the records of the [project]?

MANAGER: On April 2, $1969 \ldots$. .

LASH:

DAG:

LASH:

DAG:

LASH:

DAG:

I have another difficulty and that is it is not grounds for eviction, that there have been complaints. A person might only be evicted by what the person does, otherwise the person with an animus against a tenant could call every other name about a friend and you'll get a stack of complaints and be up for eviction.

The Board will be broad-minded in that if you will just accept this, you will have no further objections for Exhibit $\mathrm{A}$ and then whatever any decision that is made based on our complaint, we will make it known. We will accept this as Exhibit $\mathrm{A}$.

Mr. Chairman, let me inquire, if I may, why this is being read to the Board. Is it for the purpose of showing the truth of the matter contained in it?

Mr. [LASH], we're not saying that these matters are true. We are saying that these complaints have been made and that is an exception to the hearsay rules.

Mr. Chairman, we're willing to stipulate that complaints have been made and if somebody is going to count the complaints we'll be willing to stipulate the number of the complaints that have been made but it seems to me that there is a great danger of prejudicing the Board against [Mrs. I] unfairly by reading into evidence complaints that are not testified to by human beings, and we've experienced the matter. Part of the objections is based on the Administrative Procedure Act which was discussed earlier and that is one of the reasons why I wanted to bring it up earlier which guarantees to tenants the right to cross-examine witnesses against them.

Mr. [LASH], the Administrative Procedure Act further states under Section 91-10 of the Hawaii Revised Statutes that oral or documentary evidence may be received.

Mr. Chairman as to right, the counsel is right, I don't like to sound like a lawyer, it is not reversible error for you to see and read bad evidence. However ...

I object to your usage of the word bad evidence. 
LASH: All right, otherwise in evidence and admissible in court. It is not reversible error as you can see. I really 。

DAG: Mr. [LASH], I must remind you that this is an exception to the hearsay rules. This is perfectly admissible in the court of law. In any court it would be perfectly admissible as being a business entry.

LASH: It is admissible for the purpose of showing that a complaint has been made. It is not admissible for the purpose of showing the truth or falsity of the complaint.

[And so on for another two pages]

The chairman of the board hardly got a word in edgewise in this discussion-and no wonder. He was not a lawyer, and there was no way he could resolve the dispute at the level at which the attorneys were going at each other. This must have been particularly frustrating for the LASH attorney who was correct in his analysis of the hearsay rule. If the evidence of the complaints were offered simply to show that complaints were made, they were not barred by the hearsay rule, and there was no reason to read the complaints to the tribunal. ${ }^{68}$ If they were offered for their truth, they did not, despite the DAG's legal argument, qualify as business records because the declarants were under no business duty when they made them, and so they should not have been admitted at all if the ordinary rules of evidence applied. However, as the LASH attorney agreed in a concession that was quickly lost in further wrangling about the hearsay rule, the board was not bound by judicial rules of evidence and so could listen to this "bad evidence" if it wished.

The hearing proceeded for sixty-one transcript pages, longer than some criminal trials. The lawyers proceeded like lawyers. Witnesses were called, examined, and cross-examined. Objections were made and argued. Ultimately the board voted to evict. LASH did not appeal to either the Authority or a court, and the tenant moved out almost three weeks before the board's deadline.

As a legal case, this one was a loser. The tenant was clearly guilty of behavior that created disturbances in violation of the lease provisions, and the LASH attorney knew it. Indeed, the theme that emerges from his examination of the witnesses is that the problems that the Authority cited stemmed from the fact that his client, an active and cantankerous woman of fifty-nine, had been misplaced in a project of quiet-seeking retirees, many of whom were in their seventies or eighties. ${ }^{69}$ The solution the LASH attorney

68. The records reporting the complaints would be hearsay; but, as the LASH attorney conceded, they would be admissible to show that a particular number of complaints had been received if that were relevant.

69. She had qualified for admission to this project, although she had not met the usual age threshold, because she met a disability standard. 
wanted was clear-he wanted his client transferred to an ordinary low-income project.

This indeed is the strategy most likely to have worked. But by attempting to implement it in a trial-type context, the LASH attorney minimized the chance that he would get his message across. For example, one incident that the Authority cited involved an occasion when Mrs. $Y$ cursed a 79-year-old woman, Mrs. $C$, in a dispute over who should have use of a clothes dryer. After briefly reviewing the incident the cross-examination proceeded:

LASH: Mrs. $C$, you never lived in public housing before this, have you?

Mrs. $C: \quad$ No.

LASH: $\quad$ You lived in a private home, I think.

Mrs. $C$ : I lived in another apartment house ... .

LASH: And you never had any experience with public housing before?

Mrs. $C: \quad$ No.

LASH: And you didn't have any friends living in low-income public housing, I take it?

Mrs. $C: \quad$ No, first time 1 ...

LASH: $\quad$ So, I assume that with your background and all, you're not used to hearing loud [indecipherable] things and great disturbances?

Mrs. $C$ : No, I didn't.

At this point there was an argument about the relevance of this line of questioning, and the Supervising Public Housing Manager ("SPHM") who was present interjected that in his experience on the projects the use of vulgar language in public housing was rare. Then Mrs. $C$, who apparently thought her veracity was being questioned interjected, "I have to tell the truth," and the LASH attorney who may have been confused by the spontaneous witnessing of the SPHM said he had missed his observation, which gave the SPHM the chance to repeat his remarks in more detail:

SPHM: $\quad$ I stated that in all my experience with public housing in the low income project, I very seldom heard words used in public as presented by witnesses here, and this I can state as a matter of fact. Well, we may have heard lots of "damn" and some of the "F" words, but some of the words that were used, they made implications that because this is in the public housing low-rent projects that the words are commonly used

LASH: Mr. Chairman, I have a witness who is a tenant in public housing who'd like to make comments later, if we can. 
On this note the cross-examination of Mrs. $C$ ended. The witness the LASH attorney promised was never produced, for as the hearing dragged on and the board began to appear as if it was impatient and ready to render a verdict, Mrs. Y's attorney simply stated that he had available a witness who would testify that profanity is quite common in low-income projects and vulgarisms are not exceptional or shocking. The witness was not presented.

But the LASH attorney misunderstood the issues. The dispute was not over whether as a matter of fact profanity is common in low-income public housing. It was over whether Mrs. $Y$ should be allowed to stay in housing either at the elderly project or in some other low-income development. The board in assessing Mrs. Y's moral fitness-which is really what they were doing-was not likely to be greatly moved by whether the targets of her vulgarity in the elderly project came from more middle-class backgrounds (a point the LASH attorney tried to make in questioning several tenant witnesses) and so were more likely to be offended by profanity than were tenants from ordinary low-income projects.

Similarly, the following dialogue at the close of Mrs. Y's direct examination was unlikely to make the case for transferring her rather than evicting.

LASH: Mrs. $Y$ is [project] a dull place?

MRS. $Y$ : Looks like a funeral parlor most. of the time. The people are elderly, and they like to make fun that I have a crooked leg, what kind of slippers you wear, if you're a little younger they make fun of the color of my lipstick, or I tint my hair, or how I comb or dress.

LASH: Do you believe that you would be happier in a housing project with younger people?

MRS. Y: Oh yes, I think so very much. That place is too dull for me, looks like a funeral parlor to me. If they'd leave me alone it would be all right... .

LASH: They don't by and large enjoy your sense of humor I take it?

MRS. $Y$ : Oh yes, not at all, but I like everybody and I would say good morning or good afternoon ... .

LASH: No further questions at this time, Mr. Chairman.

Moreover, since both the LASH attorney and the DAG were proceeding legalistically, the direct examination opened the door to a cross-examination as to credibility that revealed that Mrs. $Y$ had an arrest record extending back to 1933, which included charges of threatening police, carrying a gun, prostitution, trespassing, and drunk and disorderly conduct.

Ironically, the LASH attorney did not employ his best opportunity to argue that Mrs. Y's elderly neighbors were unduly sensitive and that a transfer was the appropriate resolution, for when he was invited to make a closing statement, he responded, "I suspect we talked enough Mr. Chairman." 


\section{$\mathrm{X}$}

\section{Alternative Approaches}

The LASH attorney went wrong at the outset of the case when he signaled his intention to treat the eviction action as a quasi-criminal legal proceeding by filing motions to dismiss, for a more definite statement of the Authority's charges, and for inspection of documentary evidence in the Authority's possession. These motions-indeed the very fact of proceeding by motion rather than with an informal phone call-indicated to the Authority that the case would be both aggressively and legalistically contested; they perhaps induced the Authority to proceed by attorney since the motions had to be referred to an attorney, and they may have led the Authority to present more witnesses than would ordinarily have testified in a case like this.

What the attorney should have done was to attempt to negotiate a transfer before the meeting. If this failed, he should have handled the case in a lowkey fashion. Cross-examination of the Authority's witnesses should have been limited to an attempt to emphasize the limited number of disturbances that Mrs. $Y$ was reported to have caused. On direct examination Mrs. $Y$ should not have been narrowly confined. Rather, she should have told a story in which she explained away those incidents that could be explained, apologized for those that could not, promised not to repeat her behavior in the future, and asked for a transfer to a low-rise, low-income unit in which she would not be living in such close proximity to her neighbors. Ideally, the lawyer would, in addition, have had Mrs. $Y$ enter an alcoholism treatment program or start attending Alcoholics Anonymous and would have had a witness present to testify to this effort at self-improvement.

In short, the attorney could have most helped his client by coaching her so that she behaved as a savvy tenant would, with or without legal counsel. But the attorney had no idea how a savvy tenant would act because he was not a repeat player before the eviction board-this was his first case. Thus, he drew on the repertoire of moves with which he was most familiar-the moves that characterize a contested criminal case. He was probably aware that these moves were poorly suited to the facts of his case and the tribunal hearing it, but he knew of no other way to proceed.

We cannot, of course, know that the approach of a savvy tenant would have been any more successful than the trial-type approach that the LASH attorney used. Indeed, if the case arose today we could be fairly certain that the final result would have been the same-an order of eviction. However the 1969 board that heard the case of Mrs. $Y$ frequently found for tenants, and a repentant Mrs. $Y$ might have moved it to give her a second chance, particularly if the Authority could have arranged a transfer which would have meant that she would no longer bother those who had complained about her.

Because board hearings are seldom transcribed, we cannot know how frequently lawyers make technical evidentiary objections like those made by the LASH attorney in Mrs. Y's case. Comments from board members indicate that this trial-type mode of contesting eviction occurs occasionally, but, 
especially in recent years, a more cooperative expository stance predominates. This is borne out by summary case decisions that indicate that lawyers most often simply make or support tenant excuses or offer plans to remedy an admitted wrong. Thus, we see in Table 6 that since about 1980 , lawyers are more likely to take a tenant style approach than a legalistic approach to board hearings. Moreover, the kind of legalism we see in Mrs. Y's case-an attempt to impose court-like ways of proceeding on board hearings-is not the only or even the usual way that lawyers act legalistically. Most legalistic arguments do not concern the conduct of the hearings but instead focus on interpretations of adequate cause for eviction or on procedural lapses such as an Authority failure to provide a tenant with adequate notice. ${ }^{70}$

We did, however, see the transcript for one case in the 1980's that looked very much like the case of Mrs. $Y$ in the evidentiary wrangling that occurred throughout. The tenant was a Samoan chief who faced eviction because of the violent behavior of his grown son. He was represented by a private attorney who was an alumnus of LASH but who had never handled public housing evictions. A long-time board member recalled this case in explaining his judgment that lawyers more often hurt tenants than help them:

Within the first 30 minutes that [tenant's] attorney had the ability to irritate everybody on the board and piss them off. In other words. and right away, they were anti-tenant. He created that atmosphere. Now, how did he do that, I don't know; if he intended to do that, I don't know. But he succeeded admirably. ${ }^{71}$

The sentiment expressed by this board member-that lawyers more often hurt than helped tenants-was shared by most board members. ${ }^{72}$ A few, however, thought that, on balance, lawyers aided tenants by forcing the board to "toe the line."

70. Without transcripts we cannot be certain that evidentiary disputes are absent from many lawyer-attended hearings. However, most of them have no witnesses apart from the tenant and project manager; the hearing summaries prepared by the board's secretary mention legal arguments made on behalf of tenants but rarely if ever note evidentiary objections; and the case files seldom include formal legal motions or expressions of lawyerly concern about the Authority's evidentiary and hearing procedure. although these are found in the files of several cases arising in the early 1970 's.

71. Except as otherwise indicated, the quotations in this article are drawn from interviews conducted by the first author in Honolulu, Hawaii, during the summer of 1987 . The interviews werc either face to face or over the telephone. All interviews were tape-recorded, and transcribed. Thus, except for the elimination of fillers like "uh" and the insertion of punctation marks, the quotations reproduce rather than paraphrase informants' remarks. Interviewees' names are not reported because the interviewees were told their names would not be used.

72. The judgment of some board members who felt this way may have been distorted by their experience with a man who had represented several Samoan tenants brought before the board. This man, a public housing tenant, Samoan chief, and self-appointed defender of Samoan interests, took a legalistic approach when defending his fellow tenants. A number of board members thought he was a lawyer, but he was not. His defenses were legally unsound, and, from a legal point of view, often bordered on the absurd. He also appealed a number of adverse board decisions to the circuit court. but because he never followed through on the appeals, the cases were always dismissed. The cases he handled are not coded as "lawver cases" in our data. 
Regardless of their global judgments, most board members would probably share the views of one tenant board member about when attorneys did help:

Well, I found that the lawyers who admitted that the tenant was wrong and had a formula or plan that the tenant would be agreeing by, that it would do. That was the most productive for the tenant. But when we had to argue about the circumstantial evidence and we had to argue about many other things then, you know, it became just mind boggling

In short, as far as the board members were concerned, attorneys were most helpful when they proceeded not legalistically but from a problemsolving perspective. This involved making admissions, excuses, and promises similar to those that unrepresented tenants often made. But the excuses and promises of represented tenants may have had more credibility than those of unrepresented tenants. Not only was a lawyer vouching for the tenant's position, but the lawyer might have mustered others-like a social worker-to vouch for a tenant's excuse or second her promises, or the lawyer might have made arrangements that helped to clear up a past problem or to guarantee future performance.

Lawyers often used the tenant style, either alone or as a component of the service style, when the problem giving rise to the eviction had either been cured before the hearing or, in all likelihood, would be cured shortly thereafter. Non-payment cases commonly followed this model since the entire debt might be paid before the hearing or a source of funds to pay the debt could often be identified. Tenant style arguments were also used in cases like Mrs. $Y$ 's where it was possible to identify an outcome like a transfer which responded to the Authority's concerns while allowing the tenant to remain in housing. In any of these circumstances the lawyer might try to persuade the Authority to cancel the eviction hearing as unnecessary. Until recent years, hearings were often cancelled, but it appears that it was the tenant's action-most commonly the payment of a rent debt-rather than the presence of an attorney that mattered. With respect to the terms of their continued occupancy, tenants seldom did better by settling "out of court" than they would have done had they appeared before the board. ${ }^{73}$

73. While tenants who setted before the hearing seldom achieved better outcomes than those the board would have imposed, there were other advantages to pre-hearing dispositions. When hearings were cancelled tenants avoided the stress of a hearing, the prolonged subjective fear of eviction, and the need to take time off from work or other activities to attend the hearing. Also, if they subsequently defaulted on the terms of the agreement and were brought up for eviction, the board would not have seen them before, and so they may have been more likely to receive a lenient disposition.

For a brief while recently, there was a more concrete gain to be derived from having a hearing dropped in a non-payment case, for the board began putting zero-balance, non-payment tenants who appeared before it on conditions. Sep supra note 16, for example. This not only imposed a verification requirement, see infir note 74 , on the next six months of rent payments but made it likely that even a slight delay in timely rental payments would result in eviction. Within a few years after this distinction arose between zero-balance tenants whose cases proceeded to hearings and those whose hearings were cancelled, it disappeared as the Authority adopted a policy of routinely bringing zero-balance tenants to a hearing. Thus, by 1987, pre-hearing settlements in non-payment cases were largely a thing of the past. 


\section{XI \\ Capitulatory Justice}

Settling matters out of court is familiar to lawyers who dispose of most cases on a negotiated pretrial basis. Not surprisingly, the Authority's records contain instances in which lawyers negotiated settlements after some discussion with the Authority about plausible disposition of a case. One also sees cases where attempts to settle got nowhere. For example, although the available records of Mrs. Y's case provide no evidence of any pretrial negotiation, it is possible that her lawyer tried to persuade the Authority before the hearing to transfer rather than evict her. In a few cases negotiated compromises of this sort were reached. Ordinarily, however, pretrial settlements involved complete capitulation to the Authority.

In non-payment cases, for example, which constituted close to threequarters of the eviction docket, pre-hearing dismissals usually occurred only after the tenant paid all or a substantial portion of the amount owing. In the Authority's records we did not encounter settlements for so many cents on the dollar. In some behavior cases, like pet cases, the tenant similarly had to comply in full with the Authority's demands to avoid a hearing. In other behavior cases, like those involving fighting or the fraudulent concealment of income, the situation was usually so egregious before the Authority decided to evict that the Authority was unwilling to entertain any solutions that would allow the tenants to remain in housing. In a few instances it appeared that a lawyer may have regarded the attainment of a negotiated settlement as an end in itself, for there were several cases in which formal documents were signed whereby the Authority agreed to drop charges or to refrain from securing a writ of possession in exchange for the tenant's agreement to move by a specific date, often a date no later than the earliest date that the Authority could have forced the tenant to move had the tenant exhausted all her legal rights.

There are several reasons why capitulatory rather than negotiated justice characterizes most eviction cases that settle without hearings. First, the tenant's liability is usually clear. In non-payment cases there is never a dispute about the existence of the rent debt that provides the legal basis for eviction. In other cases the Authority's evidence of wrongdoing is usually overwhelming, although occasionally the tenant may have a plausible defense of misunderstanding or lack of responsibility. The one-sided nature of the evidence ordinarily means that there is seldom much uncertainty about the legal situation, and there is usually little uncertainty about what the eviction board will do. While the board has disposed of similar cases in very different ways at different times, at any given time the board's dispositions have been largely predictable from the facts of the particular case. Moreover, in the early 1970's, when the board's dispositions were most lenient, the Authority's advocate before the board did not take an adversarial stance but was content to let the board do as it wished. He had no concern for his "batting average," for he did not feel that he or the Authority was hurt by board decisions to 
defer. Thus, even when tenants had a good chance of securing a favorable disposition from the board, they could wield few incentives that might induce the Authority to prefer a less than complete victory to a board solution. The result was that tenants either gave the Authority a complete victory by curing the problem or moving out, or they proceeded to a board hearing. Even when tenants were represented, hearings were unlikely to be pretermitted by compromise solutions.

A second reason why we do not see the Authority offering significant concessions to lawyers willing to negotiate is that from the Authority's perspective hearings are cheap. The board members are volunteers who receive only a token payment of $\$ 10.00$ a member per meeting plus travel expenses. The staff time that the hearing phase of the eviction process demands is not great, and no use of the staff time that would be saved by cancelling an occasional eviction hearing is important enough to justify concessions to tenants who have violated their lease obligations.

Finally, the lawyers and paralegals who represent Authority tenants generally accept the private landlord-tenant model that underlies public housing. While these attorneys would no doubt accept concessions if these could be wrung from the Authority through negotiation, they do not regard the Authority's insistence on capitulation rather than compromise as unjust. For example, between 1980 and 1987 the Authority's attitude in non-payment cases shifted from a willingness to negotiate time payment schedules before or during hearings to insistence on a hearing even when the subpoena had triggered payment of the entire debt. Moreover, at that hearing the Authority began demanding immediate eviction unless the debt had been cleared, in which case a conditional deferment was acceptable. ${ }^{74}$ LASH's attorneys and paralegals were aware of these changes and of the fact that the board invariably complied with the Authority's wishes, but they had no strong feelings about it. The change of policy from their point of view was within the Authority's rights. Consequently, by 1987, LASH usually refused to represent non-payment tenants before the board because it did not wish to invest resources in cases that were open and shut.

Non-payment tenants who sought LASH's help received advice instead. One paralegal who had dealt with a number of public housing tenants over the years paraphrased what he told those behind on their rent:

I always advise my tenants to pay off delinquent rent. If for nothing else than to convince them, remember now, if you don't pay you are bound to get evicted. I try to convince them that with a big family like yours, you are going to have a very difficult time finding housing on the outside. .. I really impress upon them that at all costs it pays for them to pay their rent, it is one thing that they had better do and keep

74. These deferrals of eviction orders were not conditioned on time payments to clear a debt since no debt existed. Instead, the usual conditions were that the rent be paid on time during the succeeding six months and that each payment be verified. Verification consisted of bringing the receipt for rent deposited at a bank to the project oflice by the rental duc date. This enabled the project manager to learn whether the condition of time payments had been met before the computer printout of bank payments was received. 
current, or they are going to get evicted. Other debts, you know, at least they are not going to lose the roof over their head ....

This tenant advocate's remarks could have been made by a project manager addressing a tenant behind in her rent and are very much like the moralistic lectures that some board members have given tenants.

\section{XII \\ Process Legalism}

Mrs. Y's case illustrated one kind of legalism, but most of the behavior we coded as legalistic does not involve an attempt to proceed before the board as if before a court. Rather, it involves legal objections to aspects of the eviction process. Such objections have taken two forms. One form challenges the fundamental legitimacy of the eviction process and the board's role in it. The second points to particular procedural defects, often of a technical nature, in the way the Authority has initiated or prosecuted a case. The first characterized a number of cases brought in the early 1970's and culminated in a lawsuit that for much of 1977 brought evictions almost to a standstill. ${ }^{75}$ The second, which was found occasionally before 1977, has since that time characterized most legalistic responses to board action. If the Authority's procedural machinery breaks down and a tenant does not receive timely notice of a hearing, or a lease violation is improperly cited or there is some similar deficiency, lawyers can almost always get an action dismissed; and it seems that such cases are often not refiled.

LASH lawyers from the start were uncomfortable with eviction board procedures. We saw this in the remarks of the attorney who called board procedures a nightmare and in the conduct of Mrs. Y"s case as well. Thus, in our earliest period the LASH response to informality was to seek to formalize board procedures. Attorneys felt that both the rules establishing the board and the board's ways of proceeding were too vague to give the guidance that proper legal representation and due process required. In 1972, for example, a LASH attorney who entered the picture only after the board had evicted his client for trouble behavior sought a copy of the Authority's rules and regulations regarding appeals. He appeared genuinely shocked to learn from the DAG to whom his letter had been referred that the Authority had no administrative rules regarding appeal because it felt that the state law (Chapter 360) establishing the eviction board was clear and sufficient. The attorney responded to the DAG's letter conveying this news by questioning the legitimacy of the eviction board on the ground that although it was authorized by state law the Authority had not established the board by rules enacted under the Hawaii Administrative Procedure Act. ${ }^{76}$ He then wrote:

75. This case was Tileia v. Chang, Civ. No. 75-0107 (D. Haw. filed Apr. 16, 1975).

76. The lawyer's claim appears to have been that even though state law explicitly allowed the Authority to process evictions through an eviction board and specified basic conditions that the board and the Authority were required to meet, the Authority, as a state administrative agency, had 
Even assuming the existence of authority for the eviction board, appeal could not be undertaken. As you indicate, HRS 360 seems specific regarding rules governing such proceedings. Assuming, arguendo, that recourse to HRS 360 would provide a clear outline of the procedure to be followed in this general kind of case, then I must honestly say that I would still not know how to prosecute the appeal in Mrs. $G$ 's specific case. I have carefully reviewed the minutes of the hearing. I do not in any way wish to appear facetious, but $I$ have no way of knowing what findings of fact the board made, nor upon what conclusions of law their decision rested. I suggest that this result would have been avoided had clear and specific procedural rules been available for the guidance of the board. ${ }^{77}$

He also expressed his shock at the way the board had proceeded:

What is to become of the present record? Will it be read by the new panel? Although I fully appreciate the need for wide evidentiary latitude in such cases, I find the "record" in this one nearly astonishing. This is most certainly not to say that any member of the panel or of the staff was prejudiced or otherwise acted improperly. It is rather to say that completely natural human curiosity does not seem to have been curbed in that manner in which the basic principles of evidence would dictate. I suggest that this kind of problem could be avoided if eviction panels were assisted by legal counsel. In this case it is difficult for me to imagine how anyone could remain impartial after reading the existing record.

Indeed, so concerned was this attorney about the board's procedural deficiencies that, at the conclusion of his argument to the Commissioners on behalf of his client, he spoke not of why his client should be allowed to stay in housing, but rather of his willingness to volunteer his services to help the eviction board get its procedural house in order.

Other cases filed by LASH attorneys at about the same time show similar objections to the absence of published rules as well as objections to the specific procedures the board did follow. For example, in a letter of appeal to the Chairman of the Authority's Board of Commissioners, the same LASH attorney who had handled Mrs. $Y$ s case complained more on his own behalf than on that of his client:

[I]n this present case and in previous cases I have had before the eviction board, I have observed that the staff has a practice of placing before the board members a statement of the case from the staff point of view. This statement invariably contains matters that the staff does not intend to prove or rely on, but which is highly prejudicial. I request that you instruct the staff not 10 place before the Commission members any such material. I am sure your deputy attorney general will understand what I mean on this point. ${ }^{7 x}$

The last sentence is particularly revealing. The attorney seems to have given up on persuading lay people of proper procedure, but is confident that the defects he alleges in the board's procedures will be obvious to and unquestioned by any legally trained person.

\footnotetext{
to reenact the state law in administrative rules before the board could be officially established. There is no evidence that this argument was ever pursued in court.

77. L.etter from LASH attorney to Deputy Attorney General (Feb. 2, 1972).

78. Ictter from LASH attorney to Chairman, Authority Board of Commissioners (Oct. 19 $197(0)$
} 


\section{XIII}

The TILeIA Case: 1975-1977

The attack on the eviction board's procedures reached its zenith and, from LASH's standpoint, achieved its greatest success in a class action lawsuit commenced in $1975 . .^{79}$ At issue was not the eviction board's procedures, but-so the parties at one time thought-its very existence.

In 1971 HUD began to move toward providing all public housing tenants with the kind of due process that Hawaii's tenants had received for over a decade. ${ }^{80}$ HUD's mechanism was to mandate a grievance procedure that provided public housing tenants with the right to an informal hearing with project management if they wished to dispute a local housing authority's actions (including in most cases decisions to seek eviction). ${ }^{81}$ If the informal hearing did not resolve the dispute, there was a further right to a formal hearing before an impartial arbitrator or, if a single person could not be agreed on, a three-person panel composed of one member chosen by each party and a third person selected by the parties' nominees. ${ }^{82}$

Although the Authority's eviction board exceeded the constitutional due process requirements enunciated by the Supreme Court in the case of Thorpe v. Housing Authority of the City of Durham, ${ }^{83}$ it did not fit the model of the HUD regulations. The Authority was aware of this and had been considering possible courses of action for some time when LASH forced the issue with its suit. ${ }^{84}$ The suit dragged on in federal court for over a year, but it was clear that LASH was correct on the merits. With this in mind, the Authority and LASH negotiated a settlement that provided for a grievance procedure following the HUD model.

The implications of this settlement for the future of the eviction board were at first unclear. At one point, as the settlement was being implemented, the Authority put all its eviction actions on hold for several months for fear that the board's procedures were invalid. At about the same time, there were, in several projects at least, tenant polls on whether the eviction board might serve as a substitute for the HUD-mandated grievance procedure. This

79. See Tileia, Civ. No. 75-0107 (D. Haw. filed Apr. 16, 1975). The case was ultimately settled, so there is no reported decision. So far as we can determine, the case did not grow out of a specific eviction action but was more in the nature of a preemptive strike at the Authority's eviction process. The rights it aimed at securing existed outside the eviction context as well as within it.

80. HUD Circulars RHM 7465.8 (Fcb. 22, 1971) and RHM 7465.9 (Feb. 22, 1971). Circular RHM 7465.8 is titled "Requirements and Recommendations to be Reflected in Tenant Dwelling Lcases for Low-Rent Public Housing Projects." Circular RHM 7465.9 bears the title "Grievance Procedures in Low-Rent Public Housing Projects."

81. Supra note 80.

82. Id.

83. 336 U.S. $670(1967)$.

84. It appears from the records of this litigation that a number of the arguments LASH used were taken from material that had been used in cases brought by federally funded legal service organizations in other jurisdictions. One LASH informant recalled that the case fit in with a national "housing law project," and was stimulated by it. 
polling suggested that there was some question about whether the Authority could continue to use its board to process evictions. ${ }^{85}$

The eviction board and its procedures were, however, neither coextensive with nor inconsistent with the HUD-mandated grievance option. On the one hand, many issues unrelated to evictions could be grieved under the HUD procedure. On the other hand, the HUD procedures specifically provided that a tenant, by grieving an issue, forfeited no other rights to which she was legally entitled. ${ }^{86}$ Since under Hawaii law public housing tenants had a right to a decision by the eviction board before they could be compelled to leave housing, tenants who grieved eviction-related issues and lost still had a right to a board hearing. ${ }^{87}$

LASH, as far as we can determine from records and interviews, took no particular stand on this issue. Their claim had been that the eviction board did not comply with HUD regulations, and not that the board had to be displaced by an institution that did comply. And LASH's activity after winning the stipulated agreement did not focus on the eviction board. Rather, LASH was concerned with the implementation of the HUD regulations and with its role in monitoring the implementation procedures to be sure that the terms of the stipulated agreement were met.

XIV

\section{RECENT History: 1979-1987}

Tileia marks a watershed in the history of the eviction board and in LASH's activities on behalf of tenants threatened with eviction. For a variety of reasons, of which this case was only a small part, the Authority after Tileia began to rationalize and toughen its entire eviction process. As we have already noted, in 1979 a full-time employee, $A$, was hired to evaluate and oversee the Authority's eviction process and to handle all cases brought before the board, and a full-time secretary was assigned to handle the paperwork that evicting tenants requires. ${ }^{8 \times}$ At about the same time, a second eviction panel was created to accelerate the pace of evictions by having the

85. The HUD grievance regulations permitted deviations from specified procedures if tenants approved. Thus the voling implies that the Authority at one point thought that unless the board was approved by its tenants as a substitute for the HUD-mandated procedure, it could no longer be used to process eviction actions.

We do not know whether votes were taken at all projects. The Authority files that we reviewed only reported the results of voting at some of the Authority's projects, but there seem to have been votes scheduled at all of them. Then there was apparently a sudden loss of interest in the voting procedure. Nothing more is recorded. It may, of course, be that some relevant records escaped us, but interviews with people who worked for the Authority at the time suggest a similar petering out of interest. Our guess is that the Authority realized that regardless of the tenants' preferences regarding grievance procedures, the board could endure.

86. Sep HUI) Circulars, supra note 80

87. Sep Haw. Rev. StAT. $\$ 360-5$ (1971). Hawaiian law has maintained this right to a hearing. Sep Haw. Rri. STAT. \$360-5 (1988).

88. Before 1979 the Supervising Public Housing Manager handled actions before the board as one of the many duties of his job, and the board's secretary was a woman who ordinarily had many olher responsibilities. 
board available to hear cases each week. Also, new board members began to be selected with an eye to their likely strictness.

In 1980, at the instance of the Authority, the Hawaii State Legislature amended the act establishing the eviction board to allow for easier service of process, to restrict appeals, and, one might have argued, to imply that the Authority had a right to an eviction if it proved a lease violation. ${ }^{89}$ Also, effective January 1, 1981, more than a decade after LASH attorneys began complaining that the hearing board should be bound by rules promulgated in accordance with the Hawaii Administrative Procedure Act, such rules were enacted. By and large, the rules simply restated long-standing procedures. Rights that tenants were given in the statute establishing the board, such as rights to notice and counsel, were confirmed. With respect to hearing procedures, the status quo was also confirmed for the rules, as we have already noted, provide: "Hearings shall be conducted in an informal manner unless otherwise required by law." 90 No rule addresses the requisites of a board decision, but the board's secretary routinely incorporates the board's decision into a statement whose boilerplate ensures that the written pronouncement always asserts legally adequate findings of fact and law. The boilerplate deals in pro forma fashion with another aspect of board procedure-the failure to report particularistic findings of fact and law-that LASH attorneys in the early 1970's had found woefully inadequate, but it does not signal greater board attention to the factual and legal issues that cases raise. Tenants fare less well under the revised procedures than they did under the earlier ones that so disturbed the LASH attorneys of the late 1960's and early 1970's. It is, however, likely that changes of this sort would have occurred even without LASH pushing legalization on the Authority, although LASH may have hastened them along.

LASH's response to the changes that have occurred in the Authority's eviction procedures has been supportive and accommodative. Again it is difficult to untangle the importance of various causes. It is likely that LASH's attorneys are more comfortable with the presence of a legally knowledgeable counterpart prosecuting evictions for the Authority than they were when they had to deal with a Supervisory Public Housing Manager who was not legally sophisticated or, occasionally, with different deputy attorney generals who, although unfamiliar with the board's procedures, were appointed to prosecute particular contested cases. LASH attorneys have also ceased challenging the board's basic ways of proceeding. Even though the board's modes of procedure and decisionmaking differ little from what they were in the late

89. See Haw. Rev. STat. $\$ \S 360-1$ to 360-9 (1988) (amended 1980). The 1980 amendment that might have been interpreted in this fashion was apparently not read in this way by $A$, who was in office when the statute passed, and it was definitely not read this way by $B$, his successor. In one memorandum we discovered, $B$ specifically noted that the board has the authority 10 withhold an eviction even when there is a lease violation. In addition, the legislative history of the 1980 amendments, including the Authority's statements on behalf of the bill, contains no suggestion that the board's discretion was to be changed.

90. Haw. Adm. Rul.s, ch. 501, \$17-501-12(c) (1981). 
1960's and early 1970's and seem to disadvantage tenants where they do differ, LASH attorneys no longer appear to be bothered by them. This may be because the procedures have now been duly enacted in accordance with HUD regulations and Hawaii administrative law and so are open to no obvious legal attack. Indeed, LASH may now regard them as legitimate. ${ }^{\prime \prime}$ The acceptance of the Authority's eviction procedures may also reflect the fact that from 1980 to 1984 many of the eviction actions handled by LASH were assigned to the same paralegal, who became a repeat player in his relations to the Authority's prosecutors and the eviction board. Finally, it must be noted that the period we are discussing corresponds with the initiation and height of the Reagan revolution. LASH attorneys in the 1980's may simply have been less radical and less aggressive in their dealings with welfare authorities than they were ten to fifteen years earlier, or they may have had fewer resources to devote to a system that, in most respects, functions fully in accord with the law.

The LASH attorneys and paralegals who have handled public housing evictions during the past decade and the three Authority employees who have prosecuted eviction actions over the same period each told the first author that they have had a good working relationship with their nominal adversaries. The characteristics of a good working relationship have, however, changed over the years. In 1980 and 1981, when $A$ was the Authority's eviction specialist, a good working relationship meant that a LASH attorney or paralegal could call $A$ and settle the case before a hearing, if a settlement was feasible. In 1987, when the board almost always evicted tenants owing money at the time of the hearing and conditionally deferred tenants who had cleared their debts, a good working relationship meant that LASH respected the Authority's actions as within its legal rights, and ordinarily refused to take non-payment cases to hearing because they were sure losers and, as such, a waste of resources.

A good working relationship does not mean that LASH now capitulates in all cases or is unwilling to be aggressive. Where it appears that the board might respond sympathetically to an aspect of a tenant's story, the LASH attorney, or more commonly a paralegal, will try to put that story before the board. Where a legal objection can be made, it will be made. But blanket challenges or objections to the board's basic procedures like those

91. There is one procedure that LASH attorneys only appear to accept: the Authority's practice with respect to stipulated agreements. Stipulated agreements are agreements that are most often entered into by tenants who, having been evicted by the board for non-payment of rent, succeed in clearing their rent debt before their opportunity to appeal has lapsed. In these circumstances the Authority's Commission will routinely ratify a stipulated agreement between the tenant and the Authority whereby the Authority agrees not to seek a writ of possession and the tenant agrees to pay her rent when due for 12 months and to waive all rights to a hearing or appeal should the Authority seck to evict her for a violation of amy lease condition. LASH's position is that requiring tenants to waive their hearing rights for future violations other than non-payment violates HUD regulations and due process. This position may well be correct. Occasionally a lawver has been able to negotiate a stipulated agreement that does not contain this objectionable clause, but ordinarily the Authority has been insistent, and I.ASH has acquiesced because each client's direct interest is to remain in housing. 
encountered in the late 1960's and early 1970's are heard only occasionally, in a few cases handled by private counsel. Nor are LASH attorneys, while accepting the board's authority and procedures, unwilling to challenge the Authority on more substantive matters. In a 1984 case, for example, LASH got a temporary restraining order to let a tenant return to her unit after the sheriff had locked her out. ${ }^{92}$ They successfully argued that the tenant had paid her entire rent debt before the Authority's writ of possession had issued and that under Hawaii's general landlord-tenant statute this stays the writ.93

Strangely enough, LASH and the Authority's tenants appear to have made little use of the grievance procedure that LASH worked so hard to achieve. We found evidence of a few formal grievances filed in the first few years after Tileia, but almost never in recent years has a board case been preceded by a grievance hearing, and the project managers report that such hearings are rare for any purpose.

The absence of formal grievance hearings also suggests a lack of militancy on the part of LASH in recent years, for at a minimum the grievance hearing is a procedural obstacle that can be placed in the way of Authority efforts to evict and so is likely to give tenants a few months more in housing.94 Moreover, in one kind of case at least, it appears that the grievance procedure might be especially beneficial. These are cases in which the tenant is accused of the fraudulent concealment of income at the time of an annual income reexamination. Because rents are based on income, the discovery of concealed income results in the assessment of backcharges. Tenants often cannot pay such charges, for they may amount to thousands of dollars; but even where the tenant might pay, the Authority will ordinarily seek to evict for the fraud, and it may even refer such cases to the state attorney general's office for prosecution. A common tenant response to such charges is to argue misunderstanding: The tenant did not know that a certain kind of incomesuch as a part-time job, overtime, temporary employment-had to be reported. Often such claims are plausible, for the tenant speaks English poorly or not at all, and there is no written record of what an income reexaminer told her.

In the early years of the grievance procedure, several tenants grieved project managers' decisions to seek their eviction for fraudulent concealment

92. This case is not reported, and the authors' confidentiality agreement with the Authority prevents the disclosure of a case name or docket number.

93. Before a final order could issue, the Authority moved to evict the tenant for chronic latencss in her rental payments. The tenant's attorney could find no legal ground to oppose this effort and consented to a dismissal of the ongoing action.

94. Under the federal regulations, in cases where the tenant poses an immediate danger to persons or property, an Authority decision to evict need not be grieved. See HUD Lease \& Grievance Procedures, $\$ 866.51,40 \mathrm{Fed}$. Reg. 33,402 (1975). It is unclear whether grieving an authority's decision to evict for non-payment of rent may be conditioned on the tenant's putting rent as it accrues in escrow. This is the case if the dispute is over the amount of rent charged, but it is not clear that this requirement extends to the decision to evict because rent is owing. In the first few years after Tileia the Authority appears to have interpreted its decision to evict for non-payment of rent as grievable without an escrow requirement. In recent years it appears that the Authority's position on this issue has changed. 
and prevailed before three-member grievance panels that bought their "misunderstanding" arguments. It is by no means clear that the eviction board would have decided the same way, for the board members' experience can make them skeptical of excuses they have heard before and may give them more faith in the Authority's procedural routines than that accorded by a panel hearing a single case. ${ }^{95}$ Moreover, even if a grievance panel found for the Authority, the tenant would have lost nothing by proceeding with the grievance, for the right to an eviction board hearing would remain.

While LASH apparently does not initiate many formal grievances, it may take advantage of another aspect of the grievance process. This is the provision for an informal hearing between the tenant and project manager that is a prelude to a formal grievance hearing. The LASH paralegal who handled most of the Authority's public housing business from 1980 through 1984 said that he saw the informal hearing as a tool that allowed him to meet with management, and that he had settled a number of cases in this way. Such cases ordinarily do not show up on the eviction board's dockets, and so we can say little about them.

It is interesting that LASH in the 1980's may have used the informal aspect of the grievance procedure but allowed cases to be brought to the eviction board rather than to a grievance panel when informal discussion did not dissuade the Authority from attempting to evict. It may be that LASH attorneys preferred the familiar-informal negotiations or a hearing before a board with procedures they had come to know well-to the ad hoc informality of a grievance panel.\%; One thing is clear: From the LASH perspective-in part because of pressure it had applied-the nightmare that was the eviction board of the late 1960's and early 1970's has ended. The board of that era was replaced by a new board with procedures that lawyers could respect.

Yet most changes are merely matters of form. The board now has legal legitimacy, for it complements rather than preempts HUD's grievance procedures, and it is authorized not only by the state statute but by duly promulgated administrative regulations. Its decisions read more like legal decisions, for they include boilerplate conclusions of law and findings of fact. The procedures before the board, on the other hand, remain essentially as they have always been, although after 1980 it is by regulation as well as practice that these procedures are informal. In fact, the only great substantive change has been that tenants, particularly those charged with non-payment of rent, are more likely to be evicted than they have ever been. Indeed, by 1987 the board had virtually surrendered the discretion to defer evictions that had once been its most distinguishing and controversial characteristic. In retrospect one can see that the systematic efforts of LASH to legalize the

95. The tenant board members appear to be particularly suspicious of tenant excuses of this type.

96. It mav also be that the use of the informal grievance hearings mentioned by one L.ASH paralcgal is less common than his remarks would suggest. We think this is a possibility because no manager told us that LASH used informal grievances to negotiate matters they would not otherwise have discussed with them. Thus our remarks in the text should be regarded as speculative. 
board's status and procedures pushed it in this direction. But one can also see that, if the variety of forces that led to the board's current practices are considered, the efforts of LASH were not that important. ${ }^{97}$ In promoting the legalization of the eviction process, LASH was pushing the Authority in precisely the direction it wanted to go. Since the Authority's cases are invariably strong and often indisputable, the Authority had little to lose in the long run by legalization.

\section{XV \\ Conclusion}

We have seen in this article that, over a twenty-year period, lawyers have from time to time involved themselves as defense counsel in the informal adjudicatory processes of the Authority's eviction board. When this occurs, it is most often a legal aid lawyer or paralegal who represents the tenant, but one time out of five a tenant's legal representation will come from the private bar. Legal representation in this setting is not common, for only about one in twelve tenants over the two decades studied have had lawyers, and in more than 40 percent of these cases the lawyers became involved only after the initial hearing. ${ }^{98}$ Thus, the hearings remain largely as they were intended-as informal hearings in which tenants without lawyers state their cases to lay judges.99

When lawyers do get involved in eviction actions they may proceed in a variety of ways. One is in a legalistic fashion. During the first ten years of the period we are investigating, this often involved attempts to transform the hearing into a more court-like proceeding or to challenge the basic legitimacy of the eviction board's procedures. More recently, the legalistic style has usually involved particularistic objections to the details of the Authority's case handling. One result of the earlier legalism was to push the Authority toward getting its legal house in order. Without making great changes in the way eviction hearings were held, the Authority acted to bring its eviction process more closely in accord with the requirements of formal law. This more legalistic stance fit in nicely with the Authority's determination to make the board more of a $\operatorname{cog}$ in the bureaucratic process of evicting tenants than a discretionary, free-standing tribunal. Ironically, as the eviction process has become more legally embedded, the tendency of tenants to be legally represented, particularly by organized legal aid, has diminished. In a situation where "guilt" is almost always clear, the Authority's increased legalism means that there is less that lawyers are uniquely equipped to do.

We see this in the rise of a second style of representation that has become more common in recent years-the tenant style. Lawyers representing tenants can often do no more than make the kinds of cases and pleas that savvy

97. See Dynamirs, supra note 8.

98. Sep supra Tables 1, 2, 3, and 4.

99. While the Authority is now represented by a lawyer, this lawyer, as we have noted, ordinarily proceceds in an informal fashion. 
tenants have always made. These pleas, perhaps, have more credibility when made by a professional intermediary than when made by a tenant, but this benefit is unclear.

Sharing characteristics of the legalistic style and the tenant style of representation is what we call the service style. Lawyers who adopt this style perform some service for the tenant that draws upon their professional knowledge but is not aimed at refuting the legal basis of the Authority's case for eviction. Examples include collecting money past due from welfare agencies, helping a tenant file for bankruptcy, or aiding a tenant to secure a divorce. This service then allows the attorney-in a tenant style argumentto claim that the problem giving rise to the eviction action has been or is likely to be resolved.

In our judgment, lawyers have helped tenants avoid eviction in about 29 percent of the cases in which they appeared. ${ }^{100}$ In about another 18 percent of the cases, it may be that their presence was crucial to a positive outcome. ${ }^{101}$ These cases, however, represent only a small fraction-our estimate is about 3 percent-of the cases on the eviction board's docket over twenty years. ${ }^{102}$ While more tenants would have benefitted from attorneys had they been generally available over the years, the number of unrepresented tenants who would have benefitted from representation is probably not large. Most unrepresented tenants either vacated without a hearing or were allowed to stay and were evicted only if they failed to meet conditions that had been set. Of those evicted at the hearing, about two-thirds were evicted for not paying their rent. Most of these tenants are unlikely to have benefitted from legal representation, although in some cases an attorney might have been able to secure welfare funds with which the tenant could have paid her debt. Finally, it is unlikely that lawyers would have been as effective with those in our sample who were unrepresented as they were with those they did represent, since the represented were presumably self-selected and selected by attorneys as people with cases likely to benefit from legal assistance.

What is far more important to a tenant's fate than the presence of an attorney are the policies that the Authority and its eviction board follow. These policies changed over the years so that by 1987 tenants brought before the board were more likely to be evicted than they had ever been. The contribution of defense lawyers to this situation was not crucial. But in pushing the Authority toward greater legalism, these lawyers were cooperating in creating the kind of process that would make eviction, regardless of charge, the dominant outcome.

It would be a mistake to conclude that lawyers have no place in the Authority's eviction process or that they cannot on occasion help individual

100. Sie supra note 56 and accompanying text.

101. Id.

102. In a large proportion of these cases, lawyers, as we have noted. represent tenants on appeal cither because they are acquired only after the board has voted to evict or because their representation before the board was unavailing. Thus, the presence of attorneys does not affect the cviction board's decisions in some cases where it affects the Authority's final action. 
tenants. But it would be equally mistaken to conclude that lawyers, by participating in this process, can make the typical tenant's situation much better. Research in other contexts is necessary to establish a more general theory of when lawyers make a difference in institutions of informal justice. This case study suggests that the kinds of cases a tribunal hears, the rules it applies, and the nature of the adversary's representation are likely to be crucial independent variables. 